\title{
Deportation Is Different: Noncitizens and Ineffective Assistance of Counsel
}

\author{
Lea McDermid $\dagger$
}

Noncitizens reasonably rely on defense counsel to inform them of immigration consequences of a guilty plea. Yet the majority of state and federal courts has denied relief to noncitizens who claim that their attorneys were ineffective by failing to inform them of the risk of deportation. This Comment critiques the case law on such claims and describes how the 1996 changes in the immigration laws heighten the certainty and severity of deportation based on a conviction. It argues that raising the standard on what constitutes effective representation of noncitizens is timely and is consistent with Supreme Court precedent and the American Bar Association standards. This Comment concludes that defense counsel should have an affirmative duty to investigate actual immigration consequences, advise noncitizen clients of those consequences, and seek to avoid or mitigate those consequences. Finally, this Comment provides examples of how defense attorneys can avoid dispositions that will trigger removal proceedings.

\section{INTRODUCTION}

Mary Anne Gehris arrived in this country from Germany when she was a little over a year old. ${ }^{1}$ Now thirty-four years old, she is a lawful permanent resident ${ }^{2}$ (liereinafter "LPR") of the United States, lives near

Copyright $@ 2001$ California Law Review, Inc. California Law Review, Inc. (CLR) is a California nonprofit corporation. CLR and the authors are solely responsible for the content of their publications.

$\dagger \quad$ J.D. Candidate, School of Law, University of California, Berkeley (Boalt Hall), 2001. I am very grateful to Norton Tooby for helping me sharpen my understanding of this issue and for generously commenting on earlier drafts of this Comment. I am also indebted to Lucas Guttentag for clarifying for me the mysteries of judicial review and discretionary relief, and to Professor Patty Blum for providing inspiration and feedback. Finally, special thanks to Fran Matthew and James Oleson for their support and patience.

1. All of the facts of Ms. Gehris' story are taken from Anthony Lewis, This Has Got Me in Some Kind of Whirlwind, N.Y. TmEs, Jan. 8, 2000, at A13.

2. Legal or lawful permanent residents (LPRs) are those who have "the status of having been lawfully accorded the privilege of residing permanently in the United States as an iminigrant ...." Immigration and Naturalization Act (INA) of $1996 \$ 101(a)(20), 8$ U.S.C. $\$ 1101(20)$. In other words, LPRs are those who have green cards and may become United States citizens. 
Atlanta, speaks with a Georgia accent, and has a husband and son who are United States citizens. In 1988, when she was twenty-three years old, she pulled another woman's hair in a quarrel over a man. She was charged with misdemeanor battery for the hair pulling and for allegedly grabbing the woman around the neck, an act which Ms. Gehris denies committing. Although no witnesses appeared in court, she pleaded guilty on the advice of a public defender. The judge gave her a one-year jail sentence, which he suspended pending her successful completion of one year's probation. Since then, she has not been in trouble with the law.

Years later, however, trouble found Ms. Gehris when she applied to become a United States citizen. After honestly answering the questions asked by the Immigration and Naturalization Service (hereinafter "INS") and providing the INS with the Georgia documents about her conviction, the government initiated removal ${ }^{3}$ proceedings against her. Under the Antiterrorism and Effective Death Penalty Act of $1996^{4}$ (hereinafter "AEDPA") and the Illegal Immigration Reform and Immigrant Responsibility Act of $1996^{5}$ (hereinafter "IIRAIRA"), the minor misdemeanor to which she pleaded guilty, with its one-year suspended sentence, is retroactively defined as an "aggravated felony," a grounds for removal. The effect is that Ms. Gehris is removable for having committed a misdemeanor in 1988 that Congress redefined in 1996 as an "aggravated felony" for immigration purposes.

The severity and unfairness of this retroactive punishment are exacerbated by the hardship it will cause her family, her ties to the community, and her lack of a prior record. Her fourteen-year-old son, who is a United States citizen hospitalized with cerebral palsy, is unable to travel with his mother to Germany. ${ }^{7}$ In addition, the offense was committed eleven years ago, and she has no other criminal convictions. Further, Ms. Gehris has an associate's degree and had been planning to enroll in Georgia State University's criminal justice program to become a private investigator. ${ }^{8} \mathrm{How}$ ever, restrictions on discretionary waivers $^{9}$ and judicial review of

3. In 1996, Congress consolidated hearings on deportation and exclusion/inadmissibility into one "removal proceeding." INA $\S 240(a)(3)$. This Comment will use the term "removal" to refer to both deportation and exclusion.

4. Pub. L. No. 104-132, 110 Stat. 1214 (1999) (effective April 24, 1996).

5. Pub. L. No. 104-208, Div. C, tit. 111, 110 Stat. 3009 (1999) (effective April 1, 1997).

6. Defined in INA $\S 101(a)(43)$. The definition of aggravated felony encompasses some crimes, such as Ms. Gehris's battery conviction, as aggravated felonies even though the legislature in the state of conviction deems them misdemeanors. See e.g., United States v. Graham, 169 F.3d 787 (3d Cir. 1999) (holding that petty theft with a one-year suspended sentence, a misdemeanor under New York law, is an aggravated felony for immigration purposes).

7. Lewis, supra note 1 .

8. Id.

9. See INA $\S 240 \mathrm{~A}(\mathrm{a})(3)$ (disqualifying noncitizens with an aggravated felony conviction from receiving cancellation of removal, which would allow them to stay in the United States); IIRAIRA $\S$ 304(b), Pub. L. No. 104-208, Div. C, tit. IlI, 110 Stat. 3009-597 (1996), repealing INA $\$ 212(c), 8$ 
removal orders ${ }^{10}$ make it impossible for the $\mathbb{N S S}$ and the courts to consider these factors that make removal particularly unjust.

Prior to AEDPA and IIRAIRA (hereinafter "the 1996 laws"), Ms. Gehris's suspended sentence for misdemeanor battery would not have caused her removal. First, her offense would not have constituted a "conviction" for immigration purposes because she served no time im jail." Second, the pre-1996 law did not classify her misdemeanor battery as an aggravated felony because the sentence imposed was less than five years. ${ }^{12}$ Even those convicted of aggravated felonies could apply for equitable relief, unless they had served five years or more in prison. ${ }^{13}$ Granted, the lavs before 1996 may have classified Ms. Gehris's misdemeanor battery conviction as a crime mvolving moral turpitude. ${ }^{14}$ Still, a smgle conviction of a crime of moral turpitude, even after the 1996 laws, does not serve as the basis for deportation if the conviction occurred more than five years ${ }^{15}$ after admission to the United States. ${ }^{16}$

The 1996 laws make the immigration consequences of a criminal conviction more certain and more severe. ${ }^{17}$ Consequently, stories like Ms.

U.S.C. $\$ 1182$ (c) (1994) (repealing the Attorney General's authority to grant discretionary relief to excludable criminal LPRs who temporarily traveled ahroad and who were domiciled in the United States for at least seven consecutive years). See also infra, Part Il.A.

10. See INA $\$ 242(a)(2)(C)$. The statute reads:

Notwithstanding any other provision of law, no court shall have jurisdiction to review any final order of removal against an alien who is removable by reason of having committed a criminal offense covered in section 212(a)(2) [aliens ineligible for admission based on certain criminal convictions] or $237(\mathrm{a})(2)(\mathrm{A})(\mathrm{iii}),(\mathrm{B}),(\mathrm{C})$, or (D) [classes of deportable aliens based on criminal convictions], or any offense covered by section 237(a)(2)(a)(ii) [multiple convictions] for which both predicate offenses are, without regard to their date of commission, otherwise covered by section $237(\mathrm{a})(2)(\mathrm{A})(\mathrm{i})$ [crimes of moral turpitude].

Id.; INA $\$ 242(\mathrm{a})(2)(\mathrm{B})$ (denying judicial review of judgments regarding discretionary relief).

11. The AEDPA expanded the definition of "conviction" to include dispositions where the judge orders "suspension of the imposition or execution of . . imprisonment or sentence in whole or in part." AEDPA, Pub. L. No. 104-132, 110 Stat. 3009-629, adding INA $\S 101$ (a)(48)(B), 8 U.S.C. $\$ 1101$ (a) (West Supp. 1999) (defining "conviction"). In addition, the Board of Immigration Appeals may treat some actions as convictions even though the state that adjudicated the charge deems it a dismissal. DAN Kesselbrenner \& Lory D. Rosenberg, Immigration Law and CRImes 2-2 (1999); see also infra Part IV.

12. See former 8 U.S.C. $\$ 1101(a)(43)(F)(1994)$ (defining an "aggravated felony" as including "a crime of violence... for which the term of imprisonment imposed, regardless of any suspension of imprisonment, is at least 5 years"), amended by IIRAIRA, Pub. L. No. 104-208, § 321(a)(3) (reducing the sentence imposed to "at least one year") (1996), codified at INA $\$ 101(\mathrm{a})(43)$ (F), \& U.S.C. $\$ 1101(a)(43)(F)(1999)$.

13. See former INA $\S 212$ (c), 8 U.S.C. $\$ 1182$ (c) (1994), repealed by IIRAIRA, Pub. L. No. 104208, Div. C, tit. III, $\$ 304(b)$, 110 Stat. 3009-597 (1996).

14. See infra Part II.A and Part IV.B for a detailed explanation of what constitutes a crime involving moral turpitude.

15. This exception is extended to ten years for certain LPRs who supplied information to assist in a criminal investigation. See INA $\$ \$ 237(\mathrm{a})(2)(\mathrm{A})(\mathrm{i})(\mathrm{I}), 245(\mathrm{j})$.

16. See INA $\S 237$ (a)(2)(A)(i).

17. See infra Part II.A. 
Gehris's are increasingly common. Crimes involving moral turpitude ${ }^{18}$ (the broadest category of removable crimes) and aggravated felonies ${ }^{19}$ (the category that carries the most severe immigration consequences) encompass most felonies and many misdemeanors. ${ }^{20}$ The 1996 laws dramatically expanded the definition of "aggravated felony," increased the number of persons "convicted" by eliminating the requirement that jail time be actually served, and reduced the minimum sentence that must be imposed to trigger removability. In effect, the INS may now remove noncitizens, ${ }^{21}$ including LPRs, ${ }^{22}$ regardless of their ties to the United States, even if they committed the removable offense ${ }^{23}$ years ago. ${ }^{24}$ In addition, noncitizens ordered removed based on a criminal conviction "shall" be

18. INA $\S 237(a)(2)(A)(i)$. The statute renders deportable:

Any alien who (I) is convicted of a crime involving moral turpitude committed within five years (or 10 years in the case of an alien provided lawful permanent resident status under section 245(j) [8 U.S.C. $\S 1255(\mathrm{j})$ ]) after the date of admission, and (II) is convicted of a crime for which a sentence of one year or longer may be imposed.

Id.; see also INA $\$ 237$ (a)(2)(A)(ii) ("Any alien who at any time after admission is convicted of two or more crimes involving moral turpitude, not arising out of a single scheme of criminal misconduct, regardless of whether confined therefor and regardless of whether the convictions were in a single trial, is deportable."). Offenses that typically fall within this category include crimes in which an intent to steal or defraud is an element (such as theft and forgery offenses), crimes in which bodily harm is threatened or caused by an intentional or reckless act (such as murder, rape, and certain manslaughter and assault offenses), and most sex offenses. Manuel D. Vargas, Representing Noncitizen Criminal Defendants in New York State 1-4 (New York State Defenders Association, 1998). See also infra note 218 (listing resources for identifying crimes of moral turpitude).

19. See INA $\S \S 237(a)(2)(A)(i i)$ (making a noncitizen deportable for a conviction of an aggravated felony), 101(a)(43) (providing an extensive definition of "aggravated felony").

20. The ten categories of crime that served as the most common basis for removal in fiscal year 1998 were: dangerous drugs (47\%), immigration (15\%), burglary (5\%), assault $(5 \%)$, larceny (3\%), robbery $(3 \%)$, weapon offenses $(3 \%)$, sexual assault $(2 \%)$, stolen vehicle $(2 \%)$, and sex offenses $(2 \%)$. See 1998 Statistical Yearbook of the Immigration and Nationalization Service $\S 6$, available at http:/www.ins.usdoj.gov/graphics/aboutins/statistics/enf98.htm (last modified Aug. 14, 2000).

21. This Comment uses the term "noncitizen" rather than "alien," except in direct quotations. The latter term is used by virtually all courts as well as the Immigration and Nationality Act (hereinafter "INA"), however the author considers "alien" to be a pejorative word that inappropriately encourages divisiveness between citizens and noncitizens.

22. See Kesselbrenner \& RosenberG, supra note 11, at 1-10 ("Even a long-term permanent resident who is convicted of an aggravated felony will almost certainly be quickly deported, permanently banished, disqualified from almost all immigration benefits, subjected to mandatory detention, and penalized by a sentence of up to twenty years in prison for illegal rcentry after deportation.").

23. Under INA $\S 237(a)$, any noncitizen "shall, upon the order of the Attorney General, be removed" for conviction of the following criminal offenses listed in INA $\S 237(a)(2)$ : a crime of moral turpitude with a potential sentence of one year or more (if committed within five years of admission), two crimes of moral turpitude, an aggravated felony, high-speed flight, a substance abuse offense (or if the noncitizen has simply been a drug abuser or addict), certain firearm offenses, crimes of domestic violence, stalking or violation of a protection order, crimes against children, and other miscellaneous offenses (emphasis added).

24. See Nancy Morawetz, Rethinking Retroactive Deportation Laws and the Due Process Clause, 73 N.Y.U. L. REV. 97, 115 (1998). 
held in INS detention, ${ }^{25}$ may be subject to removal without discretionary rehef, ${ }^{26}$ and may be ordered banished from the United States in an administrative proceeding without judicial review. ${ }^{27}$

The Sixth Amendment provides that "in all criminal prosecutions, the accused shall enjoy the right to ... have the Assistance of Counsel for his defense." $" 28$ In Strickland v. Washington, the Supreme Court interpreted the Sixth Amendment as requiring effective assistance of counsel and announced a two-prong test for determining whether criminal defendants have been deprived of this right. ${ }^{29}$ First, defendants must prove that the attorney's representation fell below an objective standard of reasonableness (hereinafter the "performance prong"). ${ }^{30}$ The Court declared, "Prevailing norms of practice as reflected in American Bar Association [(hereinafter "ABA")] standards and the like ... are guides to determining what is reasonable...."31 Second, the defendant must establish prejudice, by showing a reasonable probability that, had the attorney performed reasonably, there would have been a different outcome (hereinafter the "prejudice prong"). ${ }^{32}$ When the issue is an attorney's effectiveness im plea bargaming, the defendant satisfies the prejudice prong by showing that "there is a reasonable probability that, but for counsel's errors, he would not have pleaded guilty and would have insisted on going to trial.".

Most state and federal courts have concluded that defense counsel's failure to investigate and advise a noncitizen client of a guilty plea's actual immigration consequences does not constitute meffective assistance of counsel. ${ }^{34}$ They generally conclude that defense attorneys have no duty to investigate or advise clients of consequences collateral to the penalty directly imposed by the criminal court (hereinafter the "collateral consequences doctrine"). ${ }^{35}$

By relying on technical distinctions between collateral and direct consequences, these decisions iguore the reality that defense counsel's knowl-

25. See § INA 236(c)(1) (listing categories of criminal activity that are the basis for mandatory detention).

26. See supra note 9 and infra Part II.A.

27. See INA $\$ 242(\mathrm{a})(2)(\mathrm{C})$, supra note 10 and infra Part II.A. Expedited removal hearings for aggravated felons are conducted at prisons, prior to the completion of the noncitizen's sentence. INA $\S 238(\mathrm{a})(3)$.

28. U.S. ConsT. amend. VI. The trial-level right to counsel, created by the Sixth Amendment, applies to the States through the Fourteenth Amendment. See Gideon v. Wainwright, 372 U.S. 335, 340 (1963). The Supreme Court held that the right to counsel comprehends the right to effective assistance of counsel in Cuyler v. Sullivan, 446 U.S. 335, 344 (1980).

29. 466 U.S. 668,687 (1984).

30. Id. at $687-88$.

31. Id. at 688 (internal citations omitted).

32. Id. at 694 .

33. Hill v. Lockhart, 474 U.S. 52,59 (1985).

34. See infra, note 69.

35. See id. 
edge and advice of the actual immigration consequences is crucial for many noncitizens who, if convicted, will face not just a criminal sentence but also the penalty of removal. ${ }^{36}$ As Justice Brandeis made clear, removal may result in the loss "of all that makes life worth living." 37 Given that during 1994 over ninety-two percent of noncitizens convicted in federal district courts entered guilty pleas, ${ }^{38}$ "the importance of aliens' understanding of the immigration laws at the time of their pleas-including the possibility of applying for and obtaining... relief-can hardly be overestimated." ${ }^{39}$ Indeed, tens of thousands of people are removed annually based on convictions that are currently on the books as removable offenses. In Fiscal Year 1998 alone, the INS removed 55,489 criminal noncitizens, nearly half of whom were convicted of drug offenses, ${ }^{40}$ which is a clearly enumerated removable offense..$^{41}$

While Ms. Gehris's attorney could not foresee that Congress would enact a law that would render his advice to his client unsound, noncitizens assume they can rely on their attorneys to inform them of the actual risk of removal, and to help them make an intelligent decision on whether to plead guilty. Their reliance is justified, given the relative ease with which an attorney can determine the actual immigration consequences of a plea under current law; a consultation with an immigration attorney or an immigration handbook often can reveal if the plea bargain under consideration will result in removal and what alternatives would be more favorable. ${ }^{42}$ In a

36. See KESSELBRENNER \& ROSENBERG, supra note 11, at 1.6-1.7 and ch. 12 for a list of other immigration consequences of a conviction.

37. Ng Fung Ho v. White, 259 U.S. 276, 284 (1922).

38. Antonin Scalia, Non-citizens in the Federal Criminal Justice System, 1984-94, U.S. Department of Justice, Bureau of Justice Statistics Special Report (Aug. 1996). Similarly, in state courts, guilty pleas accounted for more than ninety-four percent of convictions occurring within one year of arrest. U.S. Department of Justice, Bureau of Justice Statistics website, http://www.ojp.usdoj.gov/bjs/cases.htm (visited Nov 29, 2000; page last revised June 23, 2000).

39. Wallace v. Reno, 24 F. Supp. 2d 104, 111 (D. Mass. 1998).

40. See 1998 Statistical Yearbook of the Immigration and Nationalization Service $\$ 6$, supra note 20 , at $6-7$. The 55,489 noncitizens removed for criminal offenses account for $28 \%$ of all noncitizens removed. Contrast this with the 1,978 noncitizens removed in fiscal year 1986 , accounting for only $4 \%$ of all removals. $I d$.

41. See INA $\$ 237(\mathrm{a})(2)(\mathrm{B})$. The statute reads:

Any alien who at any time after admission has been convicted of a violation of (or a conspiracy or attempt to violate) any law ... relating to a controlled substance . . . other than a single offense involving possession for one's own use of 30 grams or less of marijuana, is deportable.

Id.; INA $\S 237(\mathrm{a})(2)(\mathrm{C})(\mathrm{ii})$ ("Any alien who is, or at any time after admission has been, a drug abuser or addict is deportable."); INA $\$ 212(a)(2)(A)(I)$ ("[A]ny alien convicted of, or who admits having committed ... a violation of (or a conspiracy or attempt to violate) any law ... relating to a controlled substance ... is inadmissible.").

42. For national publications, see, for example, IMMIGRANTS IN CouRTS (Joanne I. Moore, ed. 1999); Kesselbrenner \& Rosenberg, supra note 11; Norton ToOby, Criminal Defense of IMMIGRANTS (1999). For state-specific handbooks, see, for example, ANN BENSON \& JAY W. Stansell, Immigration Consequences of Criminal. Convictions (1999); William E. Gagen, Jr., Deferred Entry of Judgment, Diversion, and Preplea Probation Report, in CALIFoRNIA CRIMINAL LAw 
climate of increasing intolerance toward noncitizens with criminal convictions, ${ }^{43}$ it is critical that defense attorneys investigate and, pursuant to their clients' wishes, help their clients avoid immigration consequences of a guilty plea.

This Comment argues that, assuming prejudice is established, a defense attorney's failure to investigate and advise a noncitizen client of the actual immigration consequences of a guilty plea constitutes ineffective assistance of counsel and justifies withdrawal of a guilty plea. Part 1 summarizes the case law on ineffective assistance of counsel, including the various interpretations of defense attorneys' duties under the Strickland performance prong. It argues that courts have erred in reasoning that defense attorneys need not inform defendants of collateral consequences because judges have no duty to do so.

Part II argues that immigration consequences should not be disregarded as collateral, ${ }^{44}$ especially because the 1996 laws make the immigration consequences of a criminal conviction more certain and severe. With these changes in mind, Part II admomishes that lumping immigration consequences of aggravated felonies together with other relatively mild collateral consequences is no longer appropriate. In the alternative, Part II argues that, even if immigration consequences are technically collateral, the risk of removal is uniquely important to a defendant's decision to plead guilty or proceed to trial. Consequently, defense counsel should be required to research immigration consequences, advise clients of them, and try to avoid or minimize thein.

Part III suggests that courts abide by Strickland's call to utilize the $A B A$ standards as a guide in assessing the reasonableness of a defense attorney's performance, and proposes a test for assessing ineffective assis-

Procedure and Practice ch. 9 (2000); Manuel D. Vargas, "Strategies for Avoiding the Potential Negative Immigration Consequences of a New York Criminal Case," in Representing Noncrtizen Criminal Defendants in New York State Ch. 5, supra note 18. For a comprehensive list of law review articles, seminars, and California practice treatises and materials on the immigration consequences of criminal convictions, see Norton Tooby, et al., Request for Judicial Notice of Amici Curiae, In re Hugo Rangel Resendiz, on habeas corpus in the California Supreme Court, Case No. S078879 (2000) (on file with the author).

43. The number of people being removed is steadily increasing. See Immigration and Naturalization Service, Overview, available at http://www.ins.usdoj.gov/graphics/aboutins/thisisins/ overview.htm (last modified Nov. 11, 1999). In total, the INS removed 176,990 criminal and other noncitizens in FY 1999. Id. This is up from the 114,396 removals in FY 1997. Id. The number of criminal noncitizens removed $(62,359)$ in FY 1999 alone exceeded the total number of all noncitizens removed in FY $1995(50,414)$. Id.

44. See Guy Cohen, Note, Weaknesses of the Collateral Consequences Doctrine: Counsel's Duty to Inform Aliens of the Deportation Consequences of Guilty Pleas, 16 FoRDHAM INT'L L.J. 1094 (1993). Unlike Cohen's Note, this Comment focuses on how the 1996 changes to the Immigration and Nationality Act make the immigration consequences of a criminal conviction more certain and severe, which lends urgency to the need for reform, and it offers concrete ways in which defense counsel can avoid immigration consequences. 
tance, using those ABA standards. People v. Soriano, ${ }^{45}$ which relied on the ABA Standards of Criminal Justice in finding ineffective assistance of counsel, provides an example of how this proposed test may be applied in practice. Finally, Part IV describes the steps an effective defense attorney should take to avoid or mitigate the immigration consequences of a criminal conviction.

I

\section{Case Law on Ineffective Assistance of Counsel}

The Supreme Court laid out minimal national standards of effective representation by defense attorneys in Strickland v. Washington, holding that the Sixth Amendment right to counsel encompasses the right to effective assistance of counsel. ${ }^{46}$ The Court announced a two-prong test that criminal defendants must satisfy to have a conviction vacated based on ineffective assistance of counsel. ${ }^{47}$ First, under the "performance prong," the defendant must show that defense counsel's performance "fell below an objective standard of reasonableness." ${ }^{448}$ Performance is reasonable if the advice given is "within the range of competence demanded of attorneys in a criminal case;",49 the attorney's competence is presumed. ${ }^{50}$ Second, the defendant must satisfy the "prejudice prong" by showing that "there is a reasonable probability that, but for counsel's unprofessional errors, the result of the proceeding would have been different. A reasonable probability is a probability sufficient to undermine confidence in the outcome." same two-part test applies to ineffective-assistance claims arising out of the plea process. ${ }^{52}$ However, to prove prejudice in plea bargaining, the defendant need only show that there was "a reasonable probability that, but for counsel's errors, [the defendant] would not have pleaded guilty and would have insisted on going to trial. ${ }^{.53}$

Since a defendant will not have a claim of ineffective assistance of counsel if he fails to prove either one of the two Strickland prongs, ${ }^{54}$ many courts focus on the prejudice prong, thereby never reaching the sometimes

45. 240 Cal. Rptr. 328, 334 (Cal. Ct. App. 1987).

46. 466 U.S. 668,686 (1984).

47. Id. at 687 .

48. Id. at 688 .

49. Id. at 687 (quoting McMann v. Richardson, 397 U.S. 759, 771 (1970)).

50. Id. at 688 .

51. Id. at 694 .

52. Hill v. Lockhart, 474 U.S. 52, 57 (1985).

53. Id. at 59 (holding no prejudice where petitioner failed to allege that, had counsel correctly informed him about his parole eligibility date, he would not have pleaded guilty, and failed to allege any special circumstances that showed he placed particular emphasis on his parole eligibility in deciding whether to plead guilty).

54. Strickland, 466 U.S. at 687. 
flagrantly incompetent performance of counsel. ${ }^{55}$ Critics of defendants' rights argue that because most criminal defendants are guilty, ${ }^{56}$ they are not prejudiced by counsel's deficient performance or are not worthy of a higher standard of representation. However, this argument ignores the constitutional protections for the guilty and innocent alike. ${ }^{57}$ Moreover, in plea bargaining, the appropriate standard is not whether the defendant would have prevailed at trial if not for counsel's incompetence, but rather, whether "but for counsel's errors, he would not have pleaded guilty and would have insisted on going to trial." 58 Although courts in plea bargaining cases often mistakenly require proof of likely success at trial, ${ }^{59}$ an analysis of that inequity is outside the scope of this Comment. Rather, this Comment will focus on the performance prong since defense counsel can exercise greater control over his or her own performance than over potential prejudice.

\section{A. Adequate Representation in Non-Immigration Cases}

The standard of ineffectiveness is itself ineffective, allowing even the most egregious lawyering to pass muster. The presumption of professional reasonableness under the performance prong leaves substantial room for courts to conclude that a defense attorney's alleged inadequacies were actually informed strategy decisions, a position the Supreme Court adopted in Strickland.$^{60}$ Courts afford attorneys broad deference in decision making

55. See Martin C. Calhoun, Comment, How to Thread the Needle: Toward a Checklist-Based Standard for Evaluating Ineffective Assistance of Counsel Claims, 77 GEO. L.J. 413, $416 \mathrm{n.21}$ (1988) (finding that 291 of 702 ineffective assistance of counsel claims between 1984 and 1988 were adversely decided solely on lack of prejudice grounds).

56. E.g., Marcia Coyle et al., Trial and Error in the Nation's Death Belt; Training, Standards Lacking; Congress Debating Reform Proposals; Is Capital Justice Just a Lottery?, NaT'L L.J., June 11, 1990, at 30 (quoting Alabama Asst. Attorney General Ed Cames) ("The problem these defendants have is that 99.9 percent of them are guilty as hell. ... I don't care what kind of defense strategy you have, the jury hears the facts [of these capital crimes] and is going to give the death sentence.").

57. See, e.g., Mitchell v. United States, 526 U.S. 314, 330 (1999) (holding that in the federal criminal system, a guilty plea does not waive the Fifth Amendment's self-incrimination privilege at sentencing); Minnesota v. Carter, 525 U.S. 83, 110 (1998) (holding that Fourth Amendment protection against warrantless searches applies despite the criminality of a defendant's activities).

58. Hill v. Lockhart, 474 U.S. 52, 59 (1985).

59. See generally Emily Rubin, Ineffective Assistance of Counsel and Guilty Pleas: Toward a Paradigm of Informed Consent, 80 VA. L. Rev. 1699, 1703-05 (1994).

60. In Strickland v. Washington, 466 U.S. 668 (1984), the defendant argued that counsel had represented him ineffectively by not interviewing character witnesses, not requesting a psychiatric exainination, and not requesting a pre-sentence report. Id. at 672-73. Counsel claimed that these omissions were aimed at preventing the state from presenting counter-evidence concerning these matters and he felt that the trial judge might spare the defendant the death penalty if the defendant took responsibility for his actions. Id. The defendant was sentenced to death. Id. at 675. In spite of the gravity of the consequences of the attorney's performance, the Supreme Court held that such choices were within the range of reasonable assistance and did not constitute ineffective assistance of counsel. Id. at 699. See also infra, notes $63,65,66,67, \& 68$ (citing egregious examples of courts holding defense counsel's representation was not ineffective). 
"to protect lawyers from having strategic decisions judged with 'the distorting effects of hindsight." 61 Indeed, the Supreme Court has been wary of adopting categorical rules that would clearly define an objective standard of reasonable performance. ${ }^{62}$ The Supreme Court may be reluctant to impose a higher standard of performance by attorneys in state criminal proceedings for fear of allowing guilty defendants with poor representation to escape conviction or out of concern for already overburdened public defenders' offices.

However, permitting lower courts to interpret reasonableness has resulted in generally low performance standards, varying dramatically from state to state. For example, capital defendants in Texas are more likely to lose an ineffective-assistance claim than capital defendants in California. ${ }^{63}$ The heavy burden defendants bear is most disturbing in capital cases where courts routinely deny claims of ineffective assistance of counsel. In the most extreme cases, courts have upheld convictions even where the defense attorney fell asleep during the trial, ${ }^{64}$ was drunk, ${ }^{65}$ was under the influence of a controlled substance, ${ }^{66}$ was mentally or physically $111,{ }^{67}$ or was

61. Boria v. Keane, 99 F.3d 492, 498 (2d Cir. 1996) (quoting Strickland, 466 U.S. at 689).

62. See Strickland, 466 U.S. at $688-89$.

63. In 1997 alone, the Texas Court of Appeals turned down three petitions from death-row inmates whose lawyers slept through significant parts of their trials. See Bruce Shapiro, Sleeping Lawyer Syndrome; Murder Case in Texas, During Which the Defendant's Lawyer was Observed Sleeping, The NATion, Apr. 7, 1997, at 27. In one case, Texas executed Carl Johnson, whose attorney slept during jury selection and portions of the testimony and was later disciplined for incompetence in another death-row case. Stephen B. Bright, Sleeping on the Job, NAT'L LAw J., Dec. 4, 2000 at A26. In another case, the Texas Court of Criminal Appeals rejected a motion to reopen a capital defendant's case by a 7-to-2 margin, stating that, "we might also view [co-counsel's] decision to allow [the defense attorney] to sleep as a strategic move on his part." McFarland v. State, 928 S.W.2d 482, 505, n.20 (Tex. Crim. App. 1996). In a third case, a Texas court denied habeas corpus relief even though three jurors testified that they observed the attomey dozing and the trial judge found that counsel had slept during the trial. Ex Parte Burdine, 901 S.W.2d 456, 456-57 (Tex. Crim. App. 1995). In contrast, the Ninth Circuit held that because a defendant's counsel slept through substantial parts of the trial, he was denied his Sixth Amendment guarantee to effective assistance of counsel. Javor v. U.S., 724 F.2d 831, 833-34 (9th Cir. 1984). The Supreme Court has not yet heard a "sleeping defense counsel" appeal.

64. E.g, cases cited supra note 63.

65. E.g., Burnett v. Collins, 982 F.2d 922, 930 (5th Cir. 1993) (holding that although defendant alleged that counsel had been intoxicated during the trial and entered an alcohol treatment program after the trial, there were no specific instances where counsel's performance was deficient); Hernandez v. Wainwright, 634 F. Supp. 241, 245 (S.D. Fla. 1986) ("Even if this court were to credit . . Petitioner and his wife and determine that the mere presence of alcohol on [counsel's] breath signified inebriation, Petitioner has not shown how this condition caused [counsel] to render deficient legal representation or how this state resulted in prejudice to Petitioner's case."); People v. Garrison, 765 P.2d 419, 440 (Cal. 1989) (en banc) (holding that it was undisputed that counsel was an alcoholic and consumed large amounts of alcohol each day of the trial, but that defendant failed to prove that counsel's performance was deficient).

66. E.g., Berry v. King, 765 F.2d 451, 454 (5th Cir. 1985) ("[T]he fact that an attorney used drugs is not, in and of itself, relevant to an ineffective assistance claim. The critical inquiry is whether...counsel's performance was deficient and whether that deficiency prejudiced the defendant."); Young v. Zant, 727 F.2d 1489, 1492-93 (1Ith Cir. 1984) (finding that even though counsel admitted that he had a drug problem and was convicted for marijuana possession shortly after 
grossly inexperienced or unprepared. ${ }^{68}$ Although it may be impractical to categorically define all examples of ineffective representation, a coddling of criminal defendants would not result from a requirement that defense counsel be awake, sober, mentally competent, and prepared for trial.

\section{$B \quad$ Adequate Representation in Immigration Cases}

Courts are split on the standard of reasonable representation required of defense attorneys whose noncitizen clients face removal if they plead guilty. Courts generally apply one of three rules: (1) attorneys need not address immigration consequences at all because they are "collateral"; (2) defense attorneys must affirmatively investigate and advise clients of immigration consequences; or (3) attorneys must refrain from misinforming clients of the immigration consequences of a guilty plea.

\section{The Collateral Consequences Doctrine: No Duty to Inform of Immigration Consequences}

The vast majority of courts has denied relief altogether to noncitizen defendants who, ignorant of the risk of removal, enter a guilty plea and later claim ineffective assistance of counsel. ${ }^{69}$ These courts rely on the "collateral consequences" doctrine, which has its roots in Federal Rule of Criminal Procedure 11 (hereinafter "Rule 11") that requires courts to insure that a guilty plea is entered voluntarily. In assessing defense counsel's duty

the trial, there was no showing of ineffective assistance); State v. Coates, 786 P.2d 1182, 1187 (Mont. 1990) ("[A]bsent any specific errors or conduct identified in the trial that affected the trial's outcome, [counsel's] cocaine abuse is irrelevant to the issue of ineffective assistance of counsel.").

67. E.g., McDougall v. Dixon, 921 F.2d 518, 534 (4th Cir. 1990) (holding that although counsel was on medication and receiving treatment for depression and severe migraines, and was hospitalized several times during the trial, the defendant did not show that this affected counsel's ability to render adequate legal assistance); Smith v. Ylst, 826 F.2d 872, 876 (9th Cir. 1987) (stating that even though there was evidence of counsel's mental instability, defendant's claim of ineffective assistance was properly denied without a hearing).

68. E.g., United States v. Lewis, 786 F.2d 1278, 1281 (5th Cir. 1986) (holding not ineffective assistance where defense counsel had no prior experience in criminal advocacy); Avery v. Procunier, 750 F.2d 444, 447 (5th Cir. 1985) (holdmg not ineffective assistance where counsel appointed on the moming of trial).

69. E.g., United States v. Banda, 1 F.3d 354, 356 (5th Cir. 1993); Varela v. Kaiser, 976 F.2d 1357, 1358 (10th Cir. 1992); United States v. Del Rosario, 902 F.2d 55, 57-58 (D.C. Cir. 1990); Santos v. Kolb, 880 F.2d 941, 944-45 (7th Cir. 1989); United States v. DeFreitas, 865 F.2d 80, 82 (4th Cir. 1989); United States v. George, 869 F.2d 333, 339 (7th Cir. 1989); United States v. Quin, 836 F.2d 654, 655 (1st Cir. 1988); United States v. Yearwood, 863 F.2d 6, 7 8 (4th Cir. 1988); United States v. Campbell, 778 F.2d 764, 769 (11th Cir. 1985); United States v. Gavilan, 761 F.2d 226, 228-29 (5th Cir. 1985); United States v. Santelises, 509 F.2d 703, 704 (2d Cir. 1975); Government of Virgin Islands v. Pamphile, 604 F. Supp. 753, 756 (D.V.I. 1985); Tafoya v. State, 500 P.2d 247, 252 (Alaska 1972); State v. Ginebra, 511 So.2d 960, 962 (Fla. 1987); People v. Huante, 571 N.E.2d 736, $741-42$ (Ill. 1991); Mott v. State, 407 N.W.2d 581, 583 (Iowa 1987); Alanis v. State, 583 N.W.2d 573, 579 (Minn. 1998); People v. Dor, 505 N.Y.S.2d 317, 320 (N.Y. Sup. Ct. 1986); State v. Dalman, 520 N.W.2d 860, 863 (N.D. 1994); Commonwealth v. Frometa, 555 A.2d 92, 93-94 (Pa. 1989). 
to represent clients effectively, courts have mistakenly relied on precedent interpreting the court's obligations to defendants under Rule 11.

Rule 11 originally stated: "The court shall not accept a plea of guilty or nolo contendere without first addressing the defendant personally to determine that the defendant understands the nature of the charge and the consequences of the guilty plea." August 1, 1975 to identify more specifically what the court must explain to the defendant, and omits the language "and the consequences of the plea."71 Rule 11 continues to require trial courts to explain to the defendant, among other things, the nature of the charges and certain enumerated direct consequences of the plea, and it requires the court to insure the voluntariness of the plea. ${ }^{72}$ In spite of the 1974 amendment, some circuits have held that due process requires district courts in their jurisdiction to continue to inform defendants pleading guilty of the direct consequences of their plea and resulting conviction, in addition to the warnings required by the explicit language of current Rule 11(c). ${ }^{73}$

Courts have interpreted Rule 11 to mean that trial courts must inform defendants only of the direct consequences of the plea; advising a defendant of collateral consequences, those imposed by an institution other than the criminal court, is not required.$^{74}$ Direct consequences are those that have a "definite, immediate, and largely automatic effect on the range of punishment."75 In contrast, consequences deemed collateral by the courts include the loss of the right to vote, to work as a civil servant, to drive, to travel freely abroad, to receive an honorable discharge from the military, and to possess firearms. ${ }^{76}$ Some courts have even held that for a defendant to enter a plea voluntarily, the trial court need not advise defendants of consequences imposed by other branches of the criminal justice system. ${ }^{77}$

70. FED. R. CRIM. P. 11 (1973).

71. Fed. R. CRIM. P. 11 (2000), Advisory Committee Notes to 1974 amendment.

72. FED. R. CRIM. P. 11 (2000).

73. See, e.g., United States v. Littlejohn, 224 F.3d 960, 965 (9th Cir. 2000).

74. See, e.g., Michel v. United States, 507 F.2d 461, 466 (2d Cir. 1974) (holding that Fed. R. Crim. P. 11 requires only that the judiciary ensure that defendants understand the consequences of the sentence the court will or may impose in the criminal proceeding).

75. United States v. Littlejohn, 224 F.3d 960, 965 (9th Cir. 2000) (citing Torrey v. Estelle, 842 F.2d 234, 236 (9th Cir. 1988)); Parry v. Rosemeyer, 64 F.3d 110, 114 (3d Cir. 1995); Cuthrell v. Dir., Patuxent lnst., 475 F.2d 1364, 1366 (4th Cir. 1973).

76. E.g., United States v. Crowley, 529 F.2d 1066, 1072 (3d Cir. 1976) (loss of civil service employment); Moore v. Hinton, 513 F.2d 781, 782-83 (5th Cir. 1975) (loss of right to a driver's license); Meaton v. United States, 328 F.2d 379, 380-81 (5th Cir. 1964) (loss of right to vote and travel freely abroad); Redwine v. Zuckert, 317 F.2d 336, 338 (D.C. Cir. 1963) (undesirable discharge from the Armed Services); United States v. Cariola, 323 F.2d 180, 186-87 (3d Cir. 1963) (loss of right to vote); United States v. Casanova's, lnc., 350 F. Supp. 291, 292 (E.D. Wis. 1972) (loss of business license to sell firearms).

77. E.g., United States v. Edwards, 911 F.2d 1031, 1035 (5th Cir. 1990) (holding that state court need not advise defendant of collateral consequence of potential enhancement to other sentences); 
Courts generally agree that immigration consequences are collateral, and if a noncitizen defendant is ignorant of them because the court omitted a warning of those consequences, it will not, without additional cause, support the withdrawal of the plea under Rule $11 .^{78}$ In Fruchtman $v$. Kenton, the Ninth Circuit explained that Rule 11 imposes no duty on a court to advise a defendant of deportation because "the consequence in issue "was not the sentence of the court which accepted the plea but of another agency over which the trial judge has no control and for which he has no responsibility"."79 Furthermore, the Ninth Circuit noted, "The collateral consequences flowing from a plea of guilty are so manifold that any rule requiring a district judge to advise a defendant of such a consequence as that here involved would impose an unmanageable burden on the trial judge. $\$ 80$

The majority of courts has extended the collateral consequences doctrine to encompass ineffective assistance of counsel cases, thereby relieving defense counsel from the duty to investigate or inform their clients of the actual risk of removal. ${ }^{81}$ In denying failure-to-advise claims of ineffective assistance of counsel on the basis of the collateral consequences doctrine, the majority of appellate courts has concluded implicitly that defense attorneys owe no greater a duty to their clients than that owed by criminal trial court judges.

Paradiso v. United States, 482 F.2d 409, 415 (3d Cir. 1973) (holding that court need not advise defendant that prison terms may be imposed consecutively rather than concurrently for plea on more than one charge); Cuthrell v. Dir., Patuxent Inst., 475 F.2d at 1366 (holding that court need not advise defendant of the possible collateral consequence of commitment to state mental institution). But see United States v. Neely, 38 F.3d 458, 461 (9th Cir. 1994) (holding that the court must advise defendant that the federal court lacks discretion to order a concurrent sentence before he can enter a voluntary plea of guilty); Strader v. Garrison, 611 F.2d 61, 65 (4th Cir. 1979) ("[T]hough parole eligibility dates are collateral consequences ... when [a defendant] is grossly misinformed about it by his lawyer, and relies upon that misinformation, he is deprived of his constitutional right to counsel.").

78. See KesSElbRENIER \& RosenberG, supra note 11.

79. Fruchtman v. Kenton, 531 F.2d 946, 949 (9th Cir. 1976) (quoting Michel v. United States, 507 F.2d 461, 465 (2d Cir. 1974)).

80. Id.; see also Michel, 507 F.2d at 465 (holding that Rule 11 does not affect the long-standing rule that the trial judge, when accepting a plea of guilty, is not bound to inquire whether a defendant is aware of the collateral effects of his plea). For a contrary view, see Priscilla Budeiri, Comment, Collateral Consequences of Guilty Pleas in the Federal Criminal Justice System, 16 HARv. C.R.-C.L. L. REv. 157, 199-203 (1981) (arguing that judges should be required to present defendants with lists of all possible legal consequences stemming from guilty pleas; this would place a minimal burden on the courts and would guarantee that defendants are aware of the consequences of their pleas). Some states have statutes requiring criminal court judges to advise defendants that they may face removal if they are not citizens. E.g., Cal. Penal Code \$ 1016.5 (West 2000); ConN. Gen. Stat. \$ 54-lj (West 1987); Mass. Gen. Laws ch. 278, \$29D (1981); N.Y. Crim. Proc. Law \$ 220.50(7); Ohio Rev. Code $\$$ 2943.03.1; Or. Rev. Stat. \$ 135.385(2)(d) (1983); Tex. Crim. Proc. Code AnN. art. 26.13(a)(4) (1992); Wash. Rev. Code $\$ 10.40 .200$ (1985); Fla. Rule of CRIM. Proc. 3.172(c)(viii).

81. See supra note 69 . Even states that have granted relief have conceded that immigration consequences are collateral. See, e.g., Villavende v. State, 504 So. 2d 455, (Fla. Dist. Ct. App. 1987); lllinois v. Huante, 571 N.E.2d 736 (Ill. 1991); Mott v. State, 407 N.W.2d 581 (Iowa 1987); Commonwealth v. Frometa, 555 A.2d 92 (Pa. 1989). 
However, equating the duties of defense counsel with the courts ignores the fact that defense counsel's representation clearly involves unique responsibilities. These responsibilities include investigating mitigating factors, researching relevant case law, and advocating for the least harmful disposition for a client. ${ }^{82}$ For example, it is the duty of the defense attorney, not the trial court, to bring and argue a motion to suppress evidence. Not surprisingly, the Second Circuit stated, "Defense counsel is in a much better position to ascertain the personal circumstances of his client so as to determine what indirect consequences the guilty plea may trigger. Rule $11 \ldots$ was not intended to relieve counsel of his responsibilities to his client." 83 Thus, even conceding that advising defendants of all collateral consequences may impose an unmanageable burden on trial courts, this reasoning may not be used to excuse defense counsel's failure to advise clients of collateral consequences. The ABA standards, discussed in Part 11I, reinforce the principle that attorneys have a heightened responsibility for protecting their clients' interests that far exceeds the scope of a judge's role as a neutral arbiter.

\section{Duty Not to Misinform of Immigration Consequences}

Some courts have vacated guilty pleas only where defense attorneys misinformed their clients of the potential immigration consequences, leading their clients to believe that they would not be removed. ${ }^{84}$ This middle ground between "no duty" and an "affirmative duty" is a step in the right direction; the analysis correctly emphasizes the duty of defense counsel rather than focusing on the institution imposing the consequence or the immediacy of the consequence. However, this line of cases does not go far enough. In effect, this rule entitles defendants to effective representation of their interests as noncitizens, but only if they ask for it. The injustice of this disparate treatment is exacerbated by the fact that noncitizen defendants are typically less familiar with American law than their United States citizen counterparts. Such a rule not only confuses the roles of attorneys and their clients, it also smacks of discrimination based on alienage.

82. See infra Part IV.

83. Michel, 507 F.2d at 466.

84. E.g., Downs-Morgan v. United States, 765 F.2d 1534, 1541 (11th Cir. 1985) (holding that defense counsel's affirmative misrepresentation of the risk of deportation may constitute ineffective assistance of counsel); People v. Correa, 485 N.E.2d 307, 312 (Ill. 1985) (holding ineffective assistance of counsel where noncitizen's attorney, without conducting appropriate research and without relevant experience, advised noncitizen that guilty plea would not have immigration consequences); Morales v. Texas, 910 S.W.2d 642, 646 (Tex. Ct. App. 1995) (holding ineffective assistance of counsel where counsel provided erroneous advice about defendant's possible sentence and failed to inform defendant of the deportation consequences associated with her guilty plea). 


\section{Deportation Is Different: An Affirmative Duty to Investigate, Inform and Advise}

Solne courts have interpreted Strickland as imposing a more stringent standard of effective representation, finding ineffective assistance of counsel when attorneys fail to investigate and advise their noncitizen clients of the immigration consequences of a guilty plea. ${ }^{85}$ While generally recogmizing that removal is a collateral consequence, courts granting relief have reasoned that, because the penalty of deportation is so extreme, defense attorneys have a duty to inform noncitizen clients of this potential consequence. ${ }^{86}$ They have emphasized the "drastic" nature of removal, ${ }^{87}$ its likeness to "banishment" 88 or "a life sentence in exile," fact that immigration consequences are "unique, severe, and worthy of recognition." $" 90$

An illustration of the attorney's duty to investigate and inform can be seen in People v. Pozo. ${ }^{91}$ Pozo's attorney did not investigate the potential immigration consequences of his client's guilty plea, nor did he advise his client about possible removal. ${ }^{92}$ Reasoning that "the potential deportation consequences of guilty pleas in criminal proceedings brought against alien defendants are material to critical phases of such proceedings," the court remanded the case for a determination of whether Pozo's attorney had reason to know that he was a noncitizen. ${ }^{93}$ The court concluded, "When defense counsel in a criminal case is aware that his client is an alien, he may reasonably be required to investigate relevant immigration law." 94

California courts have similarly protected noncitizen criminal defendants' rights to effective counsel. ${ }^{95}$ In People $v$. Soriano, the defense

85. See People v. Soriano, 240 Cal. Rptr. 328, 336 (Cal. Ct. App. 1987); People v. Pozo 746 P.2d 523, 529 (Colo. 1987) (en banc); People v. Padilla, 502 N.E.2d 1182, 1185 (Ill. App. Ct. 1986); Commonwealth v. Wellington, 451 A.2d 223, 225 (Pa. Super. Ct. 1982); Edwards v. State, 393 So. 2d 597, 599-600 (Fla. Dist. Ct. App. 1981).

86. See cases cited supra note 85 .

87. People v. Correa, 485 N.E. $2 \mathrm{~d}$ at 311.

88. Commonwealth v. Wellington, 451 A.2d at 225 (quoting Ng Fung Ho v. White, 259 U.S. 276, $284(1922))$.

89. People v. Correa 485 N.E. $2 \mathrm{~d}$ at 311.

90. People v. Pozo, 712 P.2d 1044, 1047 (Colo. Ct. Appl. 1985), rev'd on other grounds, 746 P.2d 523 (Colo. 1987).

91. 746 P.2d 523 (Colo. 1987) (en banc).

92. Id. at 529 .

93. Id.

94. Id.

95. See People v. Soriano, 240 Cal. Rptr. 328, 334 (Cal. Ct. App. 1987). However, in the 2000 term, the California Supreme Court granted review on whether it constitutes ineffective assistance of counsel to fail to investigate and advise a defendant of the immigration consequences of a guilty plea. In re Resendiz, 83 Cal. Rptr. 2d 721 (Cal. Ct. App. 1999), review granted and opinion depublished by In re Resendiz, 981 P.2d 39 (Cal. 1999). Relying on Soriano, 240 Cal. Rptr. 328, the California Court of Appeals held that Resendiz's attorney's failure to research the law and adequately advise his client of the immigration consequences of his guilty plea constituted ineffective assistance of counsel. The 
attorney advised her client that he "could" be removed if he pleaded guilty. ${ }^{96}$ Noting that the attorney knew her client was a noncitizen and that she admitted to not having fully investigated the relevant immigration law, the California Court of Appeals held that Soriano had been deprived of effective assistance of counsel. ${ }^{97}$ In holding that the attorney's performance was unreasonable, ${ }^{98}$ the Soriano court relied on the ABA Standards of Criminal Justice, in accordance with the Strickland decision. The court concluded that the "pro forma caution" from his attorney was inconsistent with the commentary to the American Bar Association's Standards for Criminal Justice standard 14-3.2. ${ }^{99}$ That commentary notes that while

the court must inquire into the defendant's understanding of the possible consequences at the time the plea is received ...., this is not a substitute for advice by counsel. The court's warning, coming as it does just before the plea is taken, may not afford time for mature reflection. ${ }^{100}$

The court looked to that same standard in holding that "whatever advice his counsel did give him was not founded on adequate investigation of federal immigration law."101 Soriano's reliance on the ABA standards provides a model for a just standard of effective assistance of counsel, and it is a model supported by Strickland, as will be discussed in Part III.

II

Immigration Consequences Should Not Be

DisRegarded as Collateral

\section{A. The 1996 Changes in Immigration Law}

When Congress amended the Immigration and Nationality Act by enacting the 1996 laws, the new provisions dramatically increased the number of noncitizens whose criminal convictions make them removable. In a

court vacated his conviction and ordered the lower court to permit him to withdraw his guilty plea. This opinion was depublished when the California Supreme Court granted review. In re Resendiz, 981 P.2d 39.

96. 240 Cal. Rptr. at 334.

97. Id. at 336.

98. Id.

99. Id.

100. Id. (quoting 3 ABA Standards For CRIMinal Justice std. 14-3.2 (2d ed. 1980)).

101. Id. The court reasoned:

The American Bar Association's Standards for Criminal Justice, standard 14-3.2, which discusses plea agreements, provides, in pertinent part, that '(b) To aid the defendant in reaching a decision, defense counsel, after appropriate investigation, should advise the defendant of the alternatives available and of considerations deemed important by defense counsel or the defendant in reaching a decision.' The commentary to the standard notes the importance of advising a client of collateral consequences which may follow his conviction.

Id. (internal citations omitted). 
letter written on behalf of Attorney General Janet Reno, Assistant Attorney General Robert Raben noted that prior to 1996 ,

many long-time lawful permanent residents (LPR) without serious felony histories could apply for a waiver of virtually all deportation grounds. Also, in seeking relief from deportation, a respondent could attempt to prove that his or her positive equities (e.g., family ties in the United States, evidence of hardship if deportation occurs) outweighed relevant negative factors (e.g. seriousness and recentness of crimes). ${ }^{102}$

The 1996 laws reversed this approach by increasing the number of removable offenses, making detention of noncitizens convicted of crimes inandatory after entry of a final order of reinoval, reducing the processing time of claims, himiting discretionary waivers, and restricting judicial review of final reinoval orders. ${ }^{103}$

The 1996 laws expanded the definition of "aggravated felony," a category of crimes that has been stretched and distorted to include gambling offenses, prostitution crimes, and failure to appear before the court. ${ }^{104}$ Aggravated felonies carry the most severe immigration consequences:

[A]ggravated felons, including lawful permanent residents, are barred from all forms of relief from deportation and are permanently inadmissible to the United States, regardless of the length of time they have resided in the U.S., regardless of the hardship to U.S. citizen and permanent resident family members, and regardless of whether the person will face persecution if returned to their country of origin. ${ }^{105}$

Congress first introduced the term "aggravated felony" in 1988 to encompass the crimes of inurder, drug trafficking, and arms trafficking. ${ }^{106}$ Moreover, the INS could not mitiate removal proceedings unless the defendant was sentenced to five years or more and actually served time; a suspended sentence would not trigger removal proceedings.

But in 1996, Congress broadened the definition of "aggravated felony" to include inany crimes with a sentence of one year or more, ${ }^{107}$

102. Letter from Robert Raben, Assistant Attomey General, on behalf of Attomey General Janet Reno to 28 members of the House (Jan. 19, 2000), available at http://www.immigrationlinks.com/ news/news $179 . \mathrm{htm}$ (visited on Feb. 11, 2001).

103. See supra notes 9,10 , and 27.

104. See AEDPA $\$ 440(e)(1)$, codified at INA $\$ 101(a)(43), 8$ U.S.C. $\$ 1101(a)(43)$.

105. Ann Benson \& Jay W. Stansell, Nw. Immigrant Rights Proj., Immigration Consequences of Craninal Convictions 24 (1999).

106. See former INA $\S 101$ (a)(43), as amended by the Anti-Drug Abuse Act of 1988, Pub. L. No. $100-690$, 102 Stat. 4181 (1988).

107. See INA $\$ 101$ (a)(43). The IIRAIRA amended the definition of "aggravated felony" to include any of the following crimes if a court imposes a sentence of at least one year: a "crime of violence," a crime involving theft or burglary, receiving stolen property, passport or document fraud, commercial bribery, counterfeiting, forgery, trafficking in vessels with altered identification numbers, obstruction of justice, perjury, subornation of perjury, or bribery of a witness, and attempt or 
regardless of whether the person actually served jail time (for example, if the sentence was suspended and probation was granted). ${ }^{108}$ Under the new one-year threshold rule, even misdemeanors such as petty theft may be deemed an aggravated felony. ${ }^{109}$ The Third Circuit explained how this result came about:

Despite our misgivings that, in pursuit of a clearly defined legislative goal (to severely punish unlawful reentry into this country), a carelessly drafted piece of legislation has improvidently, if not inadvertently, broken the historic line of division between felonies and misdenneanors, we conclude that Congress was sufficiently clear in its intent to include certain crimes with one-year sentences in the definition of aggravated felony.' 110

Moreover, this broader definition of "aggravated felony" also applies retroactively to convictions entered prior to the enactment of the 1996 laws, so that a misdemeanor committed years ago can now be classified as an aggravated felony and come back to haunt noncitizens. ${ }^{11}$ The threat of removal thus reinains a constant possibility for any noncitizen who has ever committed any crime, regardless of positive changes in the person's lifestyle. ${ }^{112}$

The disproportionately severe penalty that the current immigration laws impose is exemplified by the immigration consequences to noncitizens convicted of driving while intoxicated (herinafter "DWI"). A DWI, which often yields no inore than a slap on the wrist for wealthy white United States citizens, ${ }^{113}$ may be considered an aggravated felony that will subject a convicted noncitizen to removal and exclusion from the United States. ${ }^{114}$ A DWI is classified as an aggravated felony because the Board of Immigration Appeals (hereinafter "BIA") has labeled it a "crime of

conspiracy to commit these offenses. Pub. L. No. 104-208, § 321(a)(3) (codified at 8 U.S.C. $\S 1101(\mathrm{a})(43)(\mathrm{F})(1997)$, amending INA $\S 101(\mathrm{a})(43)(\mathrm{F}),(\mathrm{G}),(\mathrm{P}),(\mathrm{R}),(\mathrm{S})$, and (U)). Compare former 8 U.S.C. § 1101(a)(43)(F) (1994) (defining an "aggravated felony" as including "a crime of violence... for which the term of imprisonment imposed (regardless of any suspension of imprisonment) is at least 5 years").

108. See INA § 101(a)(48); see also United States v. lgnacio Tejeda-Perez, 199 F.3d 981, 983 (8th Cir. 1999) ("Becausc Tejeda-Perez received a one to fifteen year sentence for the second-degree theft, the theft conviction is an aggravated felony ... . even though the prison sentence was suspended.").

109. See INA $\S(a)(43)(G)$ (defining as an aggravated felony "a theft offense ... for which the term of imprisonment [sic] at least one year").

110. United States v. Graham, 169 F.3d 787, 788 (3d Cir. 1999) (holding petty theft with a oneyear suspended sentence is an aggravated felony for immigration purposes).

111. See INA § 101(a)(43).

112. See, e.g., the story of Mary Anne Gchris, at supra INTRoduction.

113. For example, President George W. Bush, convicted in 1976 of a DWl, paid a fine of $\$ 150$ and had his driving privilcges suspended for one month. Bush Campaign Fends Off Truthfulness Questions after DUI Disclosure, Nov. 3, 2000, at http://www.CNN.com/2000/ALLPOLIT1CS/ Stories/11/03/bush.dui/index.html. (last visited Feb. 11, 2001).

114. Matter of Magallanes-Garcia, Interim Dec. \# 3341 (B.I.A. 1998). 
violence, a subcategory of aggravated felony." 115 The BIA has interpreted a "crime of violence" as including both crimes where a person is actually physically harmed and those offenses that have as an element "the use, attempted use, or threatened use of physical force against the person or property of another." 116 Courts are to consider only the nature of the offense in determining whether it is a crime of violence, not the underlying facts of the case. ${ }^{117}$ In a precedent-setting decision, the BIA ordered the removal of a man who was convicted of "felony aggravated driving" while intoxicated ${ }^{118}$ Subsequently, the INS initiated "Operation Last Call," under which long-time permanent residents with old DWI convictions were targeted for removal. The Fifth Circuit upheld this practice in 1999.119

By restricting discretionary relief and judicial review of final removal orders, the 1996 laws effectively stripped immigration judges and courts of their authority to balance the actual safety risks to the community against the hardship on the noncitizen. Prior to AEDPA and IIRAIRA, the INS or an immigration judge could grant discretionary, humanitarian relief under INA section 212(c) to an excludable criminal LPR if he could show physical presence in the United States for seven years. ${ }^{120}$ People convicted of aggravated felonies also were eligible for relief, provided they had not served more than five years in prison. ${ }^{121}$ Factors meriting favorable exercise of administrative discretion included family ties in the United States, hardship, and length of residence in the United States, even where adverse factors in an application were present. ${ }^{122}$ In the absence of adverse factors, the relief from reinoval was often granted. ${ }^{123}$ Indeed, one-half of those who

115. Id. at 2 .

116. Matter of Alcantar, 20 I. \& N. Dec. 801, 803 (B.I.A. 1994).

117. Id. at 813 .

118. Matter of Magallanes-Garcia, Interim Dec. \#3341.

119. See Camacho-Marroquin v. INS, 188 F.3d 649 (5th Cir. 1999). The court held it lacked jurisdiction to grant relief under INA $\$ 242(a)(2)(C)$ because the Texas felony offense of driving while intoxicated (DWI) was a "crime of violence," under INA $\$ 101(\mathrm{a})(43)(\mathrm{F})$ and thus was an aggravated felony and deportable offense. A crime of violence, the court reasoned, "involves a substantial risk that physical force against the person or property of another may be used in the course of committing the offense." 188 F.3d at 652 (quoting 18 U.S.C. $\$ 16(b)(1994)$ ). The court rejected the petitioner's argument that "operating" a vehicle while intoxicated (the language in the Texas Penal Code) includes mere use of a vehicle, and that sitting in a car with the engine running in the yard of a private residence would not pose a substantial risk of force. Id.

120. See former INA $\$ 212$ (c), 8 U.S.C. $\$ 1182$ (c) (1994) (authorizing the Attorney General authority to grant discretionary relief to returning LPRs facing exclusion), repealed by IIRAIRA, Pub. L. No. 104-208, Div. C, tit. III, $\$ 304$ (b), 110 Stat. 3009-597 (1996); Francis v. INS, 532 F.2d 268, 273 (2d Cir. 1976) (interpreting § 212(c) as applying with equal force to LPRs facing deportation); Matter of Silva, Int. Dec. \# 2532 (B.L.A. 1976) (adopting Francis nationwide).

121. See former INA \$ 212(c), 8 U.S.C. \$ 1182(c) (1994).

122. See Matter of Marin, 16 1. \& N. Dec. 581, 584-585 (B.I.A. 1978); Matter of Arai, 13, Int. Dec. \# 494, 498 (B.I.A. 1970).

123. See cases cited supra note 122. 
sought relief were granted it. ${ }^{124}$ Now aggravated felons are barred from discretionary relief, regardless of whether the person actually served jail time, precluding any determination of the individual hardships that removal will cause them. ${ }^{125}$ AEDPA also barred from humanitarian relief noncitizens convicted of controlled substances offenses, firearms offenses, offenses against national security, and two or more crinies of nioral turpitude. ${ }^{126}$

Judicial review of final removal orders has also been dramatically restricted, particularly for those facing removal on the basis of a criminal conviction. INA section 242(a)(2)(C) provides: "Notwithstanding any other provision of law, no court shall have jurisdiction to review any final order against an alien who is removable for reason of having committed [an enumerated] criminal offense." Nor niay courts review a judgment denying a noncitizen discretionary relief. ${ }^{127}$ Review for criminal noncitizens remains only to determine whether the petitioner is a noncitizen, is deportable, and is deportable for having committed an enumerated offense. ${ }^{128}$ Further, the scope of review has been restricted. Prior to 1996, "findings of fact, if supported by reasonable, substantial, and probative evidence on the record considered as a whole [were] conclusive."129 Now findings of fact are conclusive unless "any reasonable adjudicator would be coinpelled to conclude to the contrary."130 Finally, prior to the 1996 laws, a petition for review of a final order of removal triggered an autonatic stay of removal while the case was pending, except where the applicant was an aggravated

124. See Goncalves v. Reno, 144 F.3d 110, 113 (1st Cir. 1998) (holding that Congress did not intend its 1996 provisions restricting discretionary relief to apply retroactively to noncitizens whose applications were pending on the date AEDPA was enacted); Wallace v. Reno, 24 F. Supp. 2d 104, 112 (D. Mass. 1998) (same); Mojica v. Reno, 970 F. Supp. 130, 155 (E.D.N.Y. 1998) (same).

125. See AEDPA $\S 440$ (d), 110 Stat. 1214,1277 . Those who had applications for relief pending as of April 24, 1996, the date AEDPA was enacted, are still entitled to relief. See Goncalves, 144 F.3d at 113; Mojica, 970 F. Supp. at 155; Wallace, 24 F. Supp. 2d at 115. See also infra Part IV (discussing other still available avenues of relief).

126. See AEDPA $\S 440$ (d), 110 Stat. $1214,1277$.

127. INA section $242(a)(2)(B)$, as amended by IIRAIRA section 306 , provides:

[N] o court shall have jurisdiction to review-

(i) any judgment regarding the granting of relief under $\S 212(\mathrm{~h})$ [criminal offenses]; 212 (I)[fraud and misrepresentation]; $240 \mathrm{~A}$ [cancellation of removal]; $240 \mathrm{~B}$ [voluntary departure]; 245 [adjustment], or

(ii) any other decision or action of the Attorney General the authority for which is specified under this title to be in the discretion of the Attorney General, other than the granting of relief under 208(a).

See generally Richard L. Prinz, Criminal Aliens under IIRAIRA, in 1998-99 IMMIGRATION AND Nationality LAw HaNDBOOK: Basics.

128. See IIRAIRA § 306, amending INA § 242.

129. 8 U.S.C. $\S 1105(\mathrm{a})(4)(1996)$.

130. INA § $242(\mathrm{~b})(4)(\mathrm{B})$. 
felon. ${ }^{131}$ Now a stay is not granted unless the court specifically orders one. ${ }^{132}$

Where jurisdiction by way of petition for review to a court of appeals has been barred, the only potential avenue of relief remaining is via habeas corpus. A person in custody or subject to a final order of deportation ${ }^{133}$ may claim ineffective assistance of counsel in a direct appeal to the state court, and, if denied or if no state corrective process exists, he can petition for collateral habeas corpus relief in the federal court. ${ }^{134}$ Twenty-five percent of habeas petitions included claims of ineffective assistance of counsel. ${ }^{135}$ The federal court may not hear claims that were not adjudicated on the merits in state court proceedings unless the adjudication involved an unreasonable application of clearly established federal law or resulted in a decision based on an unreasonable determination of the facts. ${ }^{136}$ The question for the federal court is whether the police, prosecutor, defense counsel, or state court violated the petitioner's federal constitutional rights as set forth in the Constitution itself or by statute or Supreme Court decision. ${ }^{137}$ If the petition is successful, a federal court can issue a writ of habeas corpus, ordering that the prisoner be released from custody, the sentence reduced, or the case remanded for further proceedings such as retrial or resentencing. ${ }^{138}$

The majority of circuits has concluded that, for noncitizens who were in removal proceedings before the I996 laws took effect, habeas corpus jurisdiction to review final deportation decisions survives AEDPA and IIRAIRA. ${ }^{139}$ However, the circuits are split on whether a noncitizen who

131. 8 U.S.C. $\$ 1105(a)(3)(1996)$.

132. See INA $\S 242(\mathrm{~b})(3)(\mathrm{B})$.

133. Where a noncitizen is subject to a final order of deportation, the "custody" requirement of habeas corpus jurisdiction is satisfied, particularly where the alien has been released on condition of posting a bond. See Nakaranurack v. United States, 68 F.3d 290, 293 (9th Cir. 1995) ("[S]o long as he is subject to a final order of deportation, an alien is deemed to be 'in custody"'); Arias v. Rogers, 676 F.2d 1139, 1142 (7th Cir. 1982) (petitioner released on bond after commenccment of deportation proceedings is "in custody"); Eltayeb v. Ingham, 950 F. Supp. 95, 99 n.5 (alien released on own recognizance and subject to deportation order is "in custody"); Parco v. Morris, 426 F. Supp. 976, 978 n.4 (E.D. Pa. 1977) ("[W] here an order of deportation is outstanding the 'custody" requirement for habeas corpus jurisdiction is satisfied").

134. This is commonly referred to as the "exhaustion requirement." See 28 U.S.C. $\$ 2254$ (b)(1) (2000).

135. See Roger A. Hanson \& Henry W.K. Daley, U.S. Dep't of Justice, Bureau of Justice Statistics, Federal Habeas Corpus Review: Challenging State Criminal Convictions (Sept. 1995), at 17.

136. 28 U.S.C. $\$ 2254(\mathrm{~d})$.

137. See 28 U.S.C. § 2254(a).

138. See Hanson \& Daley, supra note 135 , at iv.

139. See Magana-Pizano v. INS, 200 F.3d 603, 609 (9th Cir. 1999); Pak v. Reno, 196 F.3d 666, 673 (6th Cir. 1999); Bowrin v. INS, 194 F.3d 483, 489 (4th Cir. 1999); Requena-Rodriquez v. Pasquarell, 190 F.3d 299, 306 (5th Cir. 1999); Jurado-Gutierrez v. Greene, 190 F.3d 1135, 1145-46 (10th Cir. 1999), cert. denied, 120 S. Ct. 1539 (2000); Shah v. Reno, 184 F.3d 719, 723-24 (8th Cir. 1999); Mayers v. INS, 175 F.3d 1289, 1301 (1 th Cir. 1999); Sandoval v. Reno, 166 F.3d 225, 236-37 (3d Cir. 1999); Goncalves v. Reno, 144 F.3d 110, 119-23 (Ist Cir. 1998), cert. denied, 526 U.S. 1004 
was placed in removal proceedings after April 1, 1997 is entitled to habeas corpus review. ${ }^{140}$ If habeas corpus review is permitted and the court enters an adverse decision, the noncitizen may then appeal to the court of appeals. ${ }^{141}$

\section{B. The 1996 Laws Make the Threat of Deportation or Detention a Direct Consequence}

Even if immigration consequences justifiably could have been labeled collateral in the past, such a characterization is no longer appropriate, at least with regard to those facing removal on the basis of an aggravated felony conviction. With the harsh 1996 amendments limiting discretionary relief and judicial review, a guilty plea to an aggravated felony has a "definite, immediate, and largely automatic effect"142 on a noncitizen defendant's ability to remain in the United States. Immigration consequences of aggravated felonies therefore fall within the scope of consequences on which defense attorneys should counsel their noncitizen clients. Moreover, aggravated felonies are clearly enumerated in the Immigration and Nationality Act, ${ }^{143}$ making them easy to identify, and defense counsel may be able to avoid removal by negotiating a sentence of 364 rather than 365 days. ${ }^{144}$

Furthermore, it has been clear since 1996 that the Attorney General shall detain those ordered removed based on a criminal conviction and "under no circumstances ... shall the Attorney General release" such persons. ${ }^{145}$ Therefore, at a minimum, it should be ineffective assistance of counsel to fail to inform clients that they will be deprived of their liberty once a final order of removal is entered against them based on a criminal conviction.

(1999). Only the Seventh Circuit has held that the transitional rules of IIRAIRA effected a repeal of habeas jurisdiction over final deportation orders. See LaGuerre v. Reno, 164 F.3d 1035, 1040 (7th Cir. 1998), cert. denied, 120 S. Ct. 1157 (2000).

140. Richardson v. Reno, 180 F.3d 1311, 1312-13 (11th Cir. 1999) (holding that Congress intended to repeal habeas jurisdiction to review immigration decisions by IIRAIRA's permanent rules); Max-George v. Reno, 205 F.3d 194, 197-98 (5th Cir. 2000) (same); but see Liang v. INS, 206 F.3d 308, 321-22 (3d Cir. 2000) (holding that because no judicial review of criminal aliens' statutory and constitutional claims remains under section $242(\mathrm{a})(2)(\mathrm{C})$, a repeal of habeas jurisdiction over immigration decisions raises serious constitutional questions); Flores-Miramontes v. INS, 212 F.3d 1133, 1137-38 (9th Cir. 2000); (holding that IIRAIRA's permanent rules do not use language explicit enough to repeal a federal court's habeas jurisdiction to review final removal orders); Calcano-Martinez v. I.N.S., 232 F.3d 328, 337-38 (2d Cir. 2000) (holding that Article III courts continue to have habeas jurisdiction under 28 U.S.C. $\S 2241$ over legal challenges to final removal orders, including statutory challenges).

141. Lujan-Armendariz v. INS, 222 F.3d 728, 734 n.10 (9th Cir. 2000).

142. United States v. Littlejohn, 224 F.3d 960, 965 (9th Cir. 2000).

143. See INA \& 10I(a)(43).

144. See, e.g., People v. Soriano, 240 Cal. Rptr. 328 (1987).

145. INA $\S 241$ (a)(2). 


\section{The "Collateralness" of Immigration Consequences Is Immaterial in Ineffective Assistance of Counsel Cases}

Even if courts refuse to abandon the collateral consequences doctrine in noncitizens' ineffective-assistance cases, distinguishing civil from criminal entities does not diminish the direct and severe impact that criminal courts' decisions have on INS judgments. The "collateralness" of immigration consequences "is immaterial in measuring the effective assistance of counsel." ${ }^{\prime 146}$ The technical distinction between collateral and direct consequences does nothing to ameliorate the suffering of those who are subject to the double punishnient of a prison sentence plus removal. As the Supreme Court has noted, "In this area of the law, involving as it may the equivalent of banishinent or exile, we do well to eschew technicalities and fictions and to deal instead with realities." 147 The reality is that removal deals not merely with people's rights to drive, vote, or work, but with their ability to remain in a country that has become their home. Many immigrants whose ineffective assistance claims are denied and who are removed leave behind spouses, children, jobs, and property. Some are held indefinitely in INS detention because their country of origin has no repatriation agreement with the United States. ${ }^{148}$

Long-standing Supreme Court precedent declares that deportation is not a form of criminal punishment, but rather a civil remedy aimed at excluding unwanted noncitizens. ${ }^{149}$ Prior to 1996 , deportation may not have deserved the label of punishment, given that the availability of discretionary waivers and judicial review of final removal orders allowed for a more humane, individualized assessment of the equity of removal. But the draconian changes wrought by the 1996 laws have transformed removal into a form of punishinent.

Just as the Supreme Court has found that 'only an unusual prisoner could be expected to think that he was not suffering a penalty when he was denied eligibility for parole,' only an unusual noncitizen defendant could be expected to think he was not suffering a penalty when he was rendered deportable and then deprived of any eligibility to seek a waiver of deportation..$^{150}$

146. Edwards v. State, 393 So. 2d 597, 599 (Fla. Dist. Ct. App. 1981) (distinguishing a trial court's obligation to advise the accused of collateral consequences from the obligation of defense counsel), rev'd by State v. Ginebra, 511 So. 2d 960 (Fla. 1987).

147. Costello v. INS, 376 U.S. 120, 132 (1964).

148. For example, the INS is detaining approximately 1,750 Cubans because the Cuban government has refused to accept them. Chi Ton Ngo v. INS, 192 F.3d 390, 395 (3rd Cir. 1999).

149. See INS v. Lopez-Mendoza, 468 U.S. 1032, 1038 (1984); Galvan v. Press, 347 U.S. 522, 531 (1954); Harisiades v. Shaughnessy, 342 U.S. 580, 594 (1952).

150. Scheidemann v. INS, 83 F.3d 1517, 1526 (3d Cir. 1996) (Sarokin, J., concurring) (internal citation omitted). 
Some courts have shown a willingness to abandon the criminal penalty/civil penalty distinction in analyzing whether an action is considered "punishment."151 Supreme Court Justice Black stated in a concurring opinion, "To banish [an immigrant] from home, family and adopted country is punishment of the most drastic kind."152 Even majority opinions of the Supreme Court have conceded that deportation is "a drastic measure and at times the equivalent of banishment or exile"153 that may result in the loss "of all that makes life worth living." 154 The Colorado Court of Appeals aptly concluded, "[T]he immigration consequences of a conviction are unique, severe, and worthy of recognition," and "labeling the consequence of deportation as collateral does not lessen its significance."155 Given the increased risk of removal based on a criminal conviction in the wake of the 1996 laws, abandoning the collateral consequences analysis in assessing the effectiveness of defense counsels' representation of noncitizens is both appropriate and timely.

III

\section{REMEMBERING Strickland}

Where defense attorneys fail to attempt to avoid or mitigate immigration consequences, courts should conclude that their performance is substandard as defined by Strickland. Courts have emphasized Strickland's deference to attorneys' strategic decisions ${ }^{156}$ and have ignored Strickland's call to use the "prevailing norms of practice as reflected in the American Bar Association [hereinafter ABA] standards ... to determine what is reasonable." 157 The ABA standards establish the duty of defense counsel to investigate and advise clients of the immigration consequences of a guilty plea and to avoid those consequences if possible. The People v. Soriano ${ }^{158}$ decision exemplifies how to apply Strickland and the ABA standards in a case where a noncitizen defendant claims ineffective assistance of counsel.

151. See, e.g., id. at 1526-27 (Sarokin, J., concurring) ("[D]eportation of aliens for the commission of crimes is clearly punishment."); Lok v. INS, 548 F.2d 37, 39 (2d Cir. 1977) ("[d]cportation is a sanction which in severity surpasses all but the most Draconian criminal penalties").

152. Lehmann v. United States, 353 U.S. 685, 691 (1957) (Black, J., concurring).

153. Fong Haw Tan v. Phelan, 333 U.S. 6, 10 (1948); Delgadillo v. Carmichael, 322 U.S. 388, 391 (1947); see also Barder v. Gonzales, 347 U.S. 637, 642 (1954) ("Although not penal in character, deportation statutes as a practical matter may inflict 'the equivalent of banishment or exile'... and should be strictly construed."); Bridges v. Wixon, 326 U.S. 135, 147 (1945) ("[A]lthough deportation technically is not a criminal punishment, it may nevertheless visit as great a hardship as the deprivation of the right to pursue a vocation or a calling.") (internal citations omitted).

154. Ng Fung Ho v. White, 259 U.S. 276, 284 (1922).

155. People v. Pozo, 712 P.2d 1044, 1046-47 (Colo. Ct. App. 1985), rev'd on other grounds by 746 P.2d 523 (Colo. 1987) (en banc) (holding that record was devoid of any evidence that defense counsel knew defendant's immigration status).

156. See, e.g., supra notes 65-68.

157. Strickland v. Washington, 466 U.S. 668,688 (1983).

158. 240 Cal. Rptr. 328, 330 (1987). 
Given the certainty and severity of immigration consequences in the aftermath of the 1996 laws, courts are urged to adopt Soriano's rule that attorneys have a duty to investigate and advise clients of the actual immigration consequences of a guilty plea. Effective counsel will take on this responsibility even when the defendant does not inquire about immigration consequences.

\section{A. The ABA Standards on Effective Assistance of Counsel and Noncitizen Clients}

The ABA standards require defense attorneys to reasonably investigate the exact immigration consequences their clients face, inform their clients of these consequences, and atternpt to minimize or avoid them before entering a plea. Even if immigration consequences are considered collateral, ABA Standard 14-3.2(f) clearly states that advising clients of collateral consequences is within the scope of defense counsel's responsibility: "To the extent possible, defense counsel should determine and advise the defendant, sufficiently in advance of the entry of any plea, as to the possible collateral consequences that might ensue from entry of the contemplated plea."159 The commentary to this standard provides:

[O]nly defense counsel is in a position to ensure that the defendant is aware of the full range of consequences that may apply in his or her case ${ }^{160} \ldots$ [C]ounsel should interview the client to determine what collateral consequences are likely to be important to a client given the client's particular personal circumstances and the charges the client faces. For example, depending on the jurisdiction, it may well be that many clients' greatest potential difficulty, and greatest priority, will be the immigration consequences of a conviction. To reflect this reality, counsel should be familiar with the basic immigration consequences that flow from different types of guilty pleas, and should keep this in mind in investigating law and fact and advising the client ${ }^{-161}$

Although this standard is newly published, the commentary makes clear that the substance of the rule remains the same as before, simply adding a separate standard that addresses the growing "number and significance of potential collateral consequences."162

Once defense counsel determines that a client is a noncitizen, the ABA standards support a requirement to investigate the actual risk of

159. ABA StANDARDS FOR CRIMINAL JUSTICE std. 14-3.2(f).

160. See also Michel v. United States, 507 F.2d 461, 466 (2d Cir. 1974) ("Defense counsel is in a much better position [than the judge] to ascertain the personal circumstances of his client so as to determine what indirect consequences the guilty plea may trigger. Rule $11 \ldots$ was not intended to relieve counsel of his responsibilities to his client.").

161. ABA STANDARDS FOR CRIMINAL JUSTICE std. 14-3.2(f) cmt.

162. Id. 
removal and other immigration consequences. ${ }^{163}$ Strickland imposes such a duty to investigate: "Counsel has a duty to make reasonable investigations or to make a reasonable decision that makes particular investigations unnecessary." 164 Standard 4-4.1, which the Eighth Circuit has adopted in measuring effective representation, states: "Defense counsel should conduct a prompt investigation of the circumstances of the case and explore all avenues leading to facts relevant to the merits of the case and the penalty in the event of conviction."165 Exploring "all avenues" should include investigating the immigration law any time an attorney represents a noncitizen defendant; such an investigation may lead to the discovery of facts and law that support a more favorable plea bargain. The ABA asserts that "[c]ompetent handling of a particular matter includes inquiry into and analysis of the factual and legal elements of the problem."166 A defense attorney, for example, may discover that the crime charged is an aggravated felony, but a slightly lesser charge is not.

After assessing the actual risk of immigration consequences, competent defense counsel will seek to avoid or mitigate immigration consequences. The ABA Standards for Criminal Justice provide: "In appropriate cases, the attorney should make special efforts to investigate the desirability of a disposition which would particularly meet the needs of the defendant... [and] should make a recommendation at the sentencing proceeding that it be utilized." 167 A confession by the client does not relieve defense counsel of the duty to advise the client of the potential immigration consequences prior to entering such a plea. The Defense Function standards of the ABA require defense attorneys to "fully investigate the case regardless of the desire of the defendant to plead guilty and ... advise the client of the probable outcome of the case."168 Thus, an attorney's failure to investigate and attempt to avoid immigration consequences cannot be considered a decision at all, let alone a strategic one.

The Strickland court warned that '[c]ounsel's actions are usually based, quite properly, on informed strategic choice made by the defendant and on information supplied by the defendant." 169 To make "strategic choices"170 regarding plea bargaining, attorneys must know the client's

163. See Part IV infra for discussion of what types of criminal dispositions can avoid or minimize immigration consequences.

164. Strickland v. Washington, 466 U.S. 668, 69I (1984); See also United States v. Burrows, 872 F.2d 915, 918 (9th Cir. 1989) (reversing conviction for failure to investigate a mental defense); Evans v. Lewis, 855 F.2d 631, 637 (9th Cir. 1988) (holding a failure to investigate "cannot be construed as a trial tactic" where counsel did not even bother to view the relevant documents that were available).

165. ABA StANDARDS FOR CRIMINAL Justice, std. 4-4. I, at 4-53 (3d ed. 1993).

166. Model Rules of Prof'l Conduct R. I.1 cmt. [5] (1999).

I67. ABA StandardS FOR CRIMINAL Justice std. I8-6.3(f)(4) (2d ed. 1986).

168. Id. (citing standards 4-4.1, 5.1(a) and 5.2(a)).

169. Strickland v. Washington, 466 U.S. 668, 691 (1984).

170. Id. 
interests (for example, to avoid removal), the relevant law, and what type of plea bargain would best serve the client's interest. ${ }^{171}$ The Supreme Court has held that mitigating evidence is relevant to sentencing hearings and should be heard. ${ }^{172}$ Accordingly, the harsh immigration consequences of a conviction is a mitigating fact that should factor in to plea negotiations. With knowledge of this important fact, attorneys can more effectively negotiate an agreement to plead to a different charge with a lower maximum exposure than the existing plea bargain, thereby eliminating, or at least minimizing, the risk of removal. For example, in People v. Soriano, the defendant was sentenced to 365 days and was removable. ${ }^{173} \mathrm{Had}$ counsel known that her client would be removed based on the conviction and sentence and negotiated a plea bargain for 364 days, her client would not have been removable. ${ }^{174}$ Failing to request a one-day shorter sentence cannot be considered a strategic decision.

\section{B. Imposing a Duty to Investigate and Inform Defendants of Immigration Consequences Does Not Unduly Burden Defense Attorneys}

Some courts reason that extending defense attorneys' duties to inform defendants of the numerous collateral consequences of a guilty plea would impose an unreasonable burden. ${ }^{175}$ But only minimal effort would be required of defense counsel to investigate immigration consequences and factor them into a plea bargain or seek to avoid a conviction altogether. As the practice literature makes clear, this can be accomplished by simply (a) ascertaining whether the client is a United States citizen, (b) if so, completing a one-page questionnaire with information provided by the client, and (c) making a five-minute phone call to an immigration attorney at a cost of approximately ten dollars. ${ }^{176}$ Because changes happen quickly in immigration law, consulting an immigration attorney is the most costeffective way to serve noncitizen clients. Other options include mvesting im a handbook that summarizes the immigration consequences of a criminal conviction (which some public defenders' offices already own) or attending a conference to obtain the necessary training.

171. See, e.g., Adkins v. State, 911 S.W.2d 334, 357 (Tenn. Crim. App. 1994) (holding that counsel's decision not to introduce mitigating evidence without taking adequate steps to determine the existence of mitigation testimony was likely based on inexperience rather than a sound strategic choice).

172. Califomia v. Brown, 479 U.S. 538, 541 (1987).

173. 240 Cal. Rptr. 328,330 (1987).

174. Id. at 335; see infra Part IV for discussion of other alternative dispositions to avoid immigration consequences.

175. See, e.g., United States v. Yearwood, 863 F.2d 6, 7 (4th Cir. 1988).

176. See supra note 42; see also interview with Norton Tooby, Esq., author of several practice manuals on the immigration consequences of criminal convictions, in Oakland, California (Nov. 3 , 2000). 
ABA Model Rule 1.1 on Competence supports a requirement that defense attorneys briefly investigate immigration consequences; it is a task within the scope of reasonable performance:

Perhaps the most fundamental legal skill consists of determining what kind of legal problems a situation may involve, a skill that necessarily transcends any specialized knowledge. A lawyer can provide adequate representation in a wholly novel field through necessary study. Competent representation can also be provided through the association of a lawyer of established competence in the field in question. ${ }^{177}$

In addition, ABA Model Rule 1.1 mandates that " $t] 0$ maintain the requisite knowledge and skill, a lawyer should engage in continuing study and education." 178 Accordingly, investigating and advising clients of immigration consequences is a "fundamental legal skill." The fact that this duty has been largely unenforced by the courts does not logically lead to the conclusion that using it as a basis now for finding ineffective assistance is unduly burdensome.

Requiring reasonable investigation simply reinforces a client's common sense expectation that the attorney will be well informed about the relevant areas of the law or will consult with another attorney who can advise on issues that potentially impact the client's decisions. Noncitizen criminal defendants may have an even greater expectation of their attorneys because the defendants are less likely to be familiar with the United States justice system and may not speak English. A requirement to investigate does not impose an undue burden on attorneys. Rather, it calls on attorneys to do what most already do: investigate the areas of law that could affect legal strategies or their clients' interests.

\section{Requirements for Effective Representation of Noncitizens}

The California Court of Appeal's legal analysis in People $v$. Soriano ${ }^{179}$ provides an excellent model for approaching the issue of ineffective assistance of counsel in cases involving noncitizen defendants. The Soriano court imposed a duty on defense attorneys to adequately investigate the immigration consequences of a guilty plea and to advise their clients of those consequences. ${ }^{180}$ It held that a failure to do so constitutes ineffective assistance of counsel, which justifies permitting withdrawal of the guilty plea. ${ }^{181}$ The noncitizen defendant, Soriano, pled guilty to a felony after asking about the risk of deportation and being advised by his attorney

177. Model Rule of Prof'L Conduct R.1.1 cmt. [2].

178. Model Rule of Prof'L Conduct R.1.1 cmt. [6].

179. 240 Cal. Rptr. 328, 330 (1987).

180. Id. at 336.

181. Id. 
that deportation "might" result. ${ }^{182}$ However, counsel admitted that she did not investigate the relevant immigration law and did not know that if his sentence had been one day less ( 364 days instead of 365), he would not be subject to removal. ${ }^{183}$ The court found her warning of the mere possibility of removal to be inadequate because, had the attorney researched the inatter, she would have known the client's plea would definitely have made him removable and he probably would not have pleaded guilty. ${ }^{184}$

The court relied on the ABA Standards of Criminal Justice in its analysis. The standards require that "where the defendant raises a specific question concerning collateral consequences (as where the defendant inquires about the possibility of removal), counsel should fully advise the defendant of these consequences." 185 The court reasoned that "[s]trategic choices inade after inadequate investigation fall short of providing effective assistance of counsel if reasonable professional judgment would not support the limitation on investigation.".186

Courts should not limit the attorney's duty to investigate and advise clients on immigration consequences to those situations, such as in Soriano, where the defendant inquires about them. Such a restriction puts the burden on the lay defendant to have soine familiarity with immigration law. Rather, part of the intake process in defense attorneys' offices should be to ask clients about their immigration status. All noncitizens residing in the Umited States care, to some extent or to a great extent, about being banished from their homes, families, jobs, and friends. Consequently, it is reasonable to impose upon defense attorneys an affirmative duty to find out if their clients are noncitizens, and, if so, to ask how important it is to them to remain in the United States. If the defendant is concerned about the risk of removal, counsel must investigate and advise the client of the actual immigration consequences, regardless of who initiates the discussion.

Courts should adopt a test of ineffective assistance of counsel for noncitizen criminal defendants similar to that in Soriano, which focuses on the Strickland two-prong ineffective assistance of counsel test and the ABA standards rather than on the collateral consequences doctrine. To prevail on a claim of ineffective assistance of counsel during plea bargaining, the noncitizen defendant should have to show: (1) defense counsel failed to investigate the immigration status of the client or the actual immigration consequences that are likely to flow from the conviction, or counsel did not adequately advise the client of those consequences; and (2) the defendant would not have pleaded guilty if he had been fully advised of the likely

182. Id.

183. Id. at 335-36.

184. Id.

185. Id. at 335 (quoting ABA Standards for Criminal Justice, std. 14-3.2 (2d ed. 1980)).

186. Id. at 334 (internal citations omitted). 
immigration consequences. ${ }^{187}$ The ABA Standards on Responsibilities of Defense Counsel, Duty to Investigate, Diligence, Competence, and the Defense Function discussed in Part III.A lend support to this test.

To ensure that all noncitizens are informed of the actual immigration consequences of a plea bargain will require not just individual defense attorneys' efforts, but also the cooperation of the courts, immigration attorneys, and state legislatures. Undoubtedly, the reasons for incompetence in the courtroom include: insufficient funds to motivate experienced attorneys to become and to continue working as public defenders, public defenders' unreasonably burdensome caseloads, lack of funds to provide rigorous training and supervision, and insufficient funding to hire experts and consultants. ${ }^{188}$ Ideally, adoption of this rule by the courts would not only prevent noncitizens from being removed based on an uninformed guilty plea, but it also would pressure state legislatures to codify the rule and invest more money in public defenders' offices to improve the quality of services to noncitizens. With proper funding, public defenders' offices could hire in-house immigration attorneys, pay for workshops on the immigration consequences of criminal convictions, or allocate funds for consultation with outside immigration attorneys. But even in the absence of systemic changes, individual defense attorneys can quickly and inexpensively address the immigration concerns of their clients by gathering information about their clients' immigration status and making a quick telephone call to an immigration attorney. ${ }^{189}$

Some states have enacted legislation requiring trial court judges to inform all defendants that they may be deported if they are noncitizens. ${ }^{190}$ Although this is a positive step toward the criminal justice system's recognition of the direct connection between criminal dispositions and immigration consequences, a rote warning of the mere possibility of deportation by the trial court is insufficient. The Soriano court agreed, concluding that the defendant had not been adequately advised, even though the judge had warned the defendant that he could be removed and the defendant told the court that he understood the advisement. ${ }^{191}$ The defense attorney argued

187. Factors contributing to this second prong should include the length of time the person has lived in the United States, his ties to the community, and the hardship that he and his family would suffer as a result of removal. Where these factors are compelling, prejudice should be presumed.

188. See Marcia Coyle et al., supra note 56.

189. See supra Part I11.B and infra Part IV.

190. E.g., Cal. Penal Code $\S 1016.5$ (West 2000) (requiring courts to advise defendants as follows: "If you are not a citizen, you are hereby advised that conviction of the offense of which you have becn charged may have the consequences of deportation, exclusion from admission to the United States, or denial of naturalization pursuant to the laws of the United States."). Similar state statutes include ConN. Gen. Stat. § 54-1j (West 1987); Mass. Gen. Laws ch. 278, § 29D (West 1981); Or. Rev. Stat. $\$ 135.385(2)$ (d) (1983); Tex. Code Crim. Proc. art. 26.13(a)(4) (1992); Wash. Rev. Code $\S 10.40 .200$ (1985); FLA. RULE OF CRIM. PRO. 3.172(c)(viii); New York Sentencing Reform Act of $1995 \& 30,74[\mathrm{~b}]$.

191. People v. Soriano, 240 Cal. Rptr. 328, 335 (1987). 
that her advisement to her client was the same as that given by the court. But the court refused to conclude that "such a formulaic warning from his own attorney" was an "adequate effort to advise a criminal defendant of the possible consequences of his plea." 192 Courts should follow the Soriano court's example and conclude that a formulaic warning from the trial court judge is insufficient notice of actual immigration consequences.

Defendants cannot make an informed analysis of the ramifications of a guilty plea if, for example, they are told they will receive probation for two years and may face deportation, because any noncitizen risks deportation when pleading guilty. Rather, to factor in the risks and benefits of such an important decision, the defendant needs to know whether the crime to which he is to plead guilty constitutes a removable offense, whether discretionary relief is available in the immigration court, and whether he may obtain judicial review of the final removal order. ${ }^{193}$

IV

\section{Avoiding Removal Based on a Criminal Conviction}

An effective defense attorney may be able to negotiate a plea agreeinent that will eliminate or reduce the risk of removal. Avoiding removal entails (in order of priority): (1) avoiding a conviction; (2) avoiding a conviction for a removable offense; (3) avoiding disqualification from eligibility for discretionary relief or judicial review; or (4) avoiding a conviction for a removable offense for which expungement of the conviction is not possible. A defense attorney should familiarize herself with the categories of removable offenses and the potential availability of discretionary relief and judicial review. However, to ensure effective representation, she should always consult an immigration attorney about the actual immigration consequences. By completing a questionnaire beforehand with the client, the expense of consulting an immigration attorney will be minimal. ${ }^{194}$

192. Id. at 336 .

193. The only uncertainty of deportation remaining would then be the rare possibility that the INS would choose not to initiate deportation proceedings. Of course, no matter how diligent a defense attomey is in researching the immigration law, future legislation retroactively could render noncitizens removable for pleading guilty to what is currently not a removable offense. See, e.g., supra text accompanying notes 1-6 (Mary Anne Gehris's case). Defense attomeys should inform clients of this possibility. However, I do not suggest that an ineffective assistance of counsel claim is the proper avenue for relief in such cases; defense attomeys' duty to their clients does not extend to having supernatural powers. See People v. Osaghae, 596 N.W.2d 911 (Mich. 1999) (holding defense attorney had no duty to predict future amendment to federal deportation statutes, when he rendered legal advice regarding defendant's plea four years before amendment).

194. See supra Part III.B. 


\section{A. Avoiding a Conviction}

In 1996, IIRAIRA broadened the definition of "conviction," which now includes

a formal judgment of guilt of the alien entered by a court or, if adjudication of guilt has been withheld, where-

(i) a judge or jury has found the alien guilty or the alien has entered a plea of guilty or nolo contendere or has admitted sufficient facts to warrant a finding of guilt, and

(ii) the judge has ordered some form of punishment, penalty, or restraint on the alien's liberty to be imposed. ${ }^{195}$

Unlike the prior definition of "conviction," this new definition does not require that the noncitizen spend any time in jail; a suspended sentence conditioned on probation may be considered an imposition of a penalty restraining the noncitizen's liberty. Consequently, whereas ensuring a person's liberty is the main priority for most citizens facing criminal charges, for many noncitizens the post-1996 definition of "conviction" shifts the priority to avoiding entering a plea or to entering a plea only on a nonremovable offense. The defense attorney can explore several avenues for avoiding a conviction; the availability and procedures of the options described below will vary from state to state and may be limited to certain offenses. ${ }^{196}$

First, a defense attorney can prevent removal by adjudicating charges in a noncriminal court. Only dispositions in criminal courts can be defined as a "conviction" for immigration purposes. ${ }^{197}$ For example, a juvenile court disposition is not considered a criminal conviction. ${ }^{198}$ Thus, if the alleged crime was committed when the defendant was under eighteen years of age, a defense attorney can prevent removal by fighting to keep the case in juvenile court.

Second, a defense attorney can attempt to defer one of the statutory elements required to constitute a "conviction," such as the plea, the verdict, or the sentence. ${ }^{199} \mathrm{~A}$ defendant cannot be found to have a "conviction" if he

195. INA § 101(a)(48)(A).

196. See, e.g., Manuel D. Vargas, "Strategies for Avoiding the Potential Negative Immigration Consequences of a New York Criminal Case," in Representing Noncitizen Criminal Defendants in New York State Ch. 5, supra note 42; Gagen, supra note 42; see generally KessELBRENNER \& RosenBERG, supra note 11, at ch. 2 .

197. Gagen, supra note 42.

198. In Re Miguel Devison-Charles, I. \& N. Dec. Int. No. 3435 (B.I.A. 2000); Matter of RamirezRivero, 18 I. \& N. Dec. 135 (B.I.A. 1981); Matter of C.M., 5 1. \& N. 327 (B.I.A. 1953) (juvenile court finding that the commission of a crime of moral turpitude does not consitute a "conviction" or trigger inadmissibility).

199. Note that most states will limit the availability of deferral options to certain types of offenses and defendants. For example, in California a deferred entry of judgment is only permissible in narcotics, drug abuse, and child abuse cases. CAL. PENAL CoDE $\$ \S 1000-1000.5,1000.12-1000.17$. The case cannot involve a crime of violence $(\$ 1000(a)(2))$, any prior probation or parole must have been successfully completcd $(\$ 1000(a)(5))$, and the defendant may not have been granted a deferred entry of 
enters a plea of not guilty or no contest, admits no facts, and has not been found guilty of any offense. A conviction, therefore, can be averted through an agreement with the prosecutor and the trial court to postpone the entry of a plea in the criminal case for a specified period of time. Some drug courts utilize this rehabilitation-based model. ${ }^{200}$ If the defendant satisfies the conditions of the agreement, for example, by completing drug counseling with no new arrests, the charges will be dismissed at the end of the deferral period. A verdict may also be deferred by agreement by having the defendant waive his right to confront witnesses and his right to a jury trial and submitting the case to a trial on paper based on the police report, the preliminary transcript, or other papers. ${ }^{201}$ As with a deferred plea, upon successful completion of the conditions of the agreement, the charges are dropped. ${ }^{202}$

Deferred imposition of "punishment, penalty, or restramt on the alien's liberty"203 is the suspension of criminal proceedings for a prescribed time period with certam conditions. ${ }^{204}$ Like the alternatives described above, the charges are dismissed once the terms of the agreement have been satisfied by the defendant, and the defendant, with certain exceptions, may legally answer that he or she has never been arrested for or charged with the diverted offense. ${ }^{205}$ Such terms can include jail time by agreement between the prosecutor and defense attorney. Since incarceration or other terms would not be ordered by the court, a penalty would not be "imposed," as defined in INA section 101(a)(48)(A). In states that do not require a guilty plea to be entered, if the defendant violates a term of the agreement, proceedings will be reinstated with no judgment against the defendant. Accordingly, the prosecution is still required to prove the charges agamst the defendant beyond a reasonable doubt. ${ }^{206}$

However, deferred adjudication is not a viable option for avoiding removal im states that require that the defendant enter a guilty plea. For example, California now requires that the defendant enter a guilty plea as a

judgment or have a felony conviction in the prior five years $(\S 1000(a)(5))$. For drug offenses, the defendant cannot have a prior controlled substance offense $(\S 100(\mathrm{a})(1))$ and only deferrable drug offenses may be involved ( $\$ 1000(a))$.

200. See, e.g., CAL. PENAL CODE $\S 1000.5$ (authorizing the establishment of a "preguilty plea drug program").

201. See Cal fornia Crminal Law Procedure and Practice, supra note 42, at Ch. 48.

202. See id.

203. 8 U.S.C. $\$ 1101(a)(48)(A)(i i)$.

204. Gagen, supra note 42, at 190.

205. See id.

206. This continues to be the practice in California for offenses committed before January $1,1997$. The 1996 revisions to CAL. Penal Code $\S \S 1000-1000.5$ (Stats 1996, ch. 1132, $\S 2$ ) added the requirement that the defendant plead guilty for entry of judgment to be deferred. 
condition of a deferred entry of judgment. ${ }^{207}$ In these states, if the defendant fails to successfully complete the conditions of the agreement, criminal proceedings resume, and the defendant, having already pleaded guilty, is sentenced. ${ }^{208}$ Furthermore, successful completion of deferred entry of judgment does not necessarily prohibit the arrest record from being used in proceedings to remove or deny admission to a noncitizen.$^{209}$ Indeed, as recently as 2000 the Ninth Circuit interpreted the new definition of "conviction" to mean that "a conviction occurs prior to the time the probationary period begins in cases processed under state deferred adjudication laws, regardless of whether the state statute requires further proceedings prior to the formal entry of a judgment of conviction in the event of a probation violation." 210 In states that follow the California model, defense counsel therefore should seek out one of the other alternatives described in this Part.

\section{B. Avoiding Convictions for Removable Offenses}

A defense attorney should look to the Immigration and Naturalization Act for a definition of general crimes that may serve as the basis for deportation ${ }^{211}$ and exclusion, ${ }^{212}$ both of which may be triggered by several categories of offenses such as crimes involving moral turpitude and aggravated felonies. Defense counsel must seek to avoid a conviction that could result in removal by securing a plea bargain to a charge with a maximum prison exposure time of less than the statutory threshold. For example, a single conviction of a crime of moral turpitude will not trigger removal unless it has been committed within five years of the last admission to the United States and the maximum sentence is one year or more. ${ }^{213}$ Many common crimes classified as aggravated felonies also require that the offense be punished by a sentence imposed of at least one year to trigger removal. ${ }^{214}$ The 1996 laws reduced the minimum term of imprisonment that

207. See CAL. Penal Code $\S 1000.1$ (b). Note, however, that counties may exercise their authority under this law to establish drug courts that can continue to grant pre-1997 style diversions with no plea. See $\$ 1000.5$. See also supra note 206.

208. See Cal. Penal Code $§ 1000.1(\mathrm{~b})$

209. Herrera-Inirio v. INS, 208 F.3d 299 (1st Cir. 2000) (holding Puerto Rico court's issuance of formal judgment of exoneration did not preclude finding that noncitizen was "convicted" for removal purposes); Moosa v. INS, 171 F.3d 994 (5th Cir. 1999) (holding that Texas deferred adjudication was "conviction" for purposes of determining whether noncitizen was ineligible for permanent residence due to felony conviction); Paredes-Umestarazu v. INS, 36 F.3d 801 (9th Cir. 1994) (holding BIA need not give effect to Califomia's trial diversion program under which noncitizen's narcotics possession charges were dismissed).

210. Lujan-Armendariz v. INS, 222 F.3d 728, 742 (9th Cir. 2000).

211. INA $\S 237(a)(2)$; see also INA $\S 101(a)(43)$ (defining “aggravated felony"); supra note 95.

212. INA $\S 212(\mathrm{a})(2)$.

213. INA $\S 237$ (a)(2)(A)(i)(1I).

214. See INA $\S 101(a)(43)$. Some offenses listed in this section do not require imposition of a oneyear minimum term of imprisonment to trigger removal (for example, murder, rape, sexual abuse of a 
must be imposed for a conviction to be considered an aggravated felony from five years to one year for the offenses with a sentence requirement. ${ }^{215}$

Determining what is a crime involving moral turpitude is no simple task. "Moral turpitude" is a nebulous term of art, and the crimes it encompasses are not enumerated in the Immigration and Nationality Act. The only guidance comes from federal court and BIA decisions. For example, one BIA decision states that moral turpitude

shocks the public conscience as being inherently base, vile, or depraved, contrary to the rules of morality and the duties owed between man and man, either one's fellow man or society in general. Moral turpitude has been defined as an act which is per se morally reprehensible and intrinsically wrong, or malum in se, so it is the nature of the act itself and not the statutory prohibition of it which renders a crime one of moral turpitude. ${ }^{216}$

The definition of a crime of moral turpitude is based on the nature of the crime and the record of conviction, rather than on the specific facts of the case. Courts have held that the following relatively minor offenses are crimes involving moral turpitude for immigration purposes: adultery, issuing bad checks, attempted bribery, disorderly conduct (loiterimg for lewd purposes or soliciting), false statement (on firearm application or passport application), forgery, mail fraud, mayhem, possession of stolen mail, receiving stolen property, and petty theft. ${ }^{217}$ Although this list is far from exhaustive, it provides some indication of the wide range of crimes that are comprehended by the definition. Because "moral turpitude" evades precise definition, it is particularly important to consult an immigration attorney when in doubt. The only alternative is for defense counsel to conduct a thorough search of the relevant case law or to consult an updated practice guide to see if the offense in question qualifies. ${ }^{218}$

minor, drug trafficking, and firearms trafficking). Id. However, because of the nature of these offenses, they often carry a minimum term of imprisonment of at least one year.

215. See, e.g., INA $\$ 101(\mathrm{a})(43)(\mathrm{F})$ (a crime of violence); (G) (a theft offense); and (P) (relating to document fraud).

216. Matter of Fualuaau, Int. Dec. \# 3285 (B.I.A. 1996).

217. DAN Kesselbrenner \& LoRy D. Roseneerg, Sample Determinations on the Issue of Moral Turpitude, in IMMIGRATION LAW AND CRIMES, app. E (2000).

218. For a summary of the crimes that have, to date, been deemed to be crimes of moral turpitude, see Kesselbrenner \& RoseneErg, Deportability and Excludability for Crimes Involving Moral Turpitude $\S 6$ and Sample Determinations on the Issue of Moral Turpitude, in IMMICRATION LAW AND CRIMES, supra note 217, at app. E; Katherme Brady, Table and Annotations of Crimes involving Moral Turpitude under the California Penal Code, in California Criminal Law and Immigration (2000); Amy Righter, Sourcelist of Cases Defining "Crimes of Moral Turpitude" Under the Immigration and Nationality Act, at http://www.criminalandimmigrationlaw.com/cmt/cmt.html (last updated Dec. 7, 2000); What Constitutes 'Crime Involving Moral Turpitude' Within Meaning of $\$ \$ 212(a)(9)$ and 241(a)(4) of Immigration and Nationality Act (8 U.S.C.A. $\$ \$ 1182(a)(9), 1251(a)(4))$, and Similar Predecessor Statutes Providing for Exclusion or Deportation of Aliens Convicted of Such Crime, 23 A.L.R. FED. 480 (2000). 


\section{Avoiding Convictions for Which No Discretionary Relief or Judicial Review Is Available}

Defense attorneys should be aware of the crimes for which relief from removal may still be sought in immigration courts and advise their clients accordingly. Although the 1996 laws significantly restricted discretionary relief, ${ }^{219}$ discretionary waivers of removal are still available for long-term lawful permanent residents convicted of all crimes other than aggravated felonies. ${ }^{220}$ For example, INA section 212(h) permits waivers for noncitizens facing inadmissibility ${ }^{221}$ based on a criminal conviction for a crime of moral turpitude, simple possession of thirty grams or less of marijuana, multiple criminal convictions for which the aggregate sentences to confinement were five years or more, prostitution-related offenses, and serious offenses for which the noncitizen was granted immunity. ${ }^{222}$ To qualify, the person must establish that denial of admission would cause "extreme hardship" to an immediate family member who is an LPR or a United States citizen. ${ }^{223}$ Alternatively, relief may be granted if: the applicant waits fifteen years between the disqualifying act and the application; the applicant's admission would not be contrary to the national welfare, safety, or security of the United States; and the applicant has been rehabilitated. ${ }^{224}$ The waiver does not apply to LPRs who have been convicted of an aggravated felony since the date of admission or if the LPR has not lived continuously in the United States for at least seven years. ${ }^{225}$

Another avenue of relief is INA section $240 \mathrm{~A}$ (a), which permits cancellation of removal for long-term LPRs convicted of certain crimes other than aggravated felonies. An LPR is eligible if he or she has been lawfully admitted for permanent residence for at least five years, has resided in the United States continuously for at least seven years after having been admitted in any status, and has not been convicted of an aggravated felony. Because a grant of cancellation of removal is at the discretion of an Immigration Judge, noncitizens facing removal may identify their individual circumstances that would make removal particularly unjust, such as

219. See supra note 9.

220. See VARGAS, supra note 42, at 3-7 to 3-9. (summarizing grounds for telief from removal for LPRs).

221. The deportability grounds are now applicable only to individuals who have been "lawfully admitted" to the United States, for example, a LPR with a green card, and who remain here. The grounds of inadmissibility, formerly referred to as exclusion, apply to everyone else. This includes persons who have entered but have not been lawfully admitted to the United States and LPRs who are stopped at a border or other port of entry upon return from a trip outside the United States. VARGAS, supra note 42 , at 1-3.

222. Multiple convictions with an aggregate sentence to confinement of five years or less do not necessarily trigger removability. INA $\S 212(\mathrm{a})(2)(\mathrm{B})$.

223. INA $\$ 212(\mathrm{~h})$.

224. Id.

225. Id. 
length of residence, family ties in the United States, and lack of a prior criminal record. An effective defense attorney may be able to negotiate down from a plea bargain requiring a guilty plea to an absolutely removable offense to an offense for which discretionary relief may be available.

\section{Expunging Convictions}

A defense attorney may be able to help clients avoid removal by expunging a conviction under a state or federal rehabilitation statute. This avenue of relief is typically only available to first-time drug offenders convicted of simple drug possession and other minor first drug convictions. For example, the Federal First Offender Act (hereinafter "FFOA") ${ }^{226}$ expunges the drug conviction of first-time drug offenders, thereby avoiding the harsh consequences that can often result from a drug conviction. This federal rehabilitation statute provides that no legal consequences may be imposed as a result of the defendant's having committed the offense. ${ }^{27}$ Under the Act the person may enter a guilty plea, which is later set aside, or defer entry of a plea and judginent of conviction. Courts have held that both types of disposition effectively erase the drug "conviction" for immigration purposes. ${ }^{228}$

The Board of Immigration Appeals has ruled that a noncitizen is not deportable if he can establish that he would have been eligible for treatment under the FFOA. ${ }^{229}$ The Ninth Circuit clarified this rule, holding that persons whose offenses qualified for treatment under the FFOA, but who were convicted and had their convictions expunged under state statutes, ${ }^{230}$ are not subject to removal on account of those offenses. ${ }^{231}$ In a separate decision, the Ninth Circuit extended this rule to convictions for drug offenses less serious than felony simple possession of a controlled substance. ${ }^{232}$ Relying solely on the possibility of an expungement involves a greater degree of risk than the other options described above, particularly

226. 18 U.S.C. $\$ 3607$ (Supp. 2000).

227. See 18 U.S.C. $\$ 3607(b)$.

228. See In re Manrique, Int. Dec. 3250 (B.1.A. 1995); Garberding v. INS, 30 F.3d 1187 (9th Cir. 1994).

229. In re Manrique, Int. Dec. 3250 (B.1.A. 1995), 1995 B.1.A. LEX1S 14, at $\div 9$.

230. See, e.g., IDAHO CODE $\S 19-2604$ (1) (2000) (providing for the retroactive setting aside of a guilty plea or conviction and dismissal of cases where the judgment was withheld or suspended and the defendant has complied with the requisite probationary conditions); ARIz. REv. STAT. $\$ 13-907$ (A) (2000) (providing that "every person convicted of a criminal offense may, upon fulfillment of the conditions of probation or sentence and discharge by the court, apply to the judge ... to have the judgment of guilt set aside"); MONT. STATUTE 46-18-204 (allowing court to dismiss the case and strike a conviction or permit withdrawal of a guilty plea by defendant whose sentence was deferred).

231. Lujan-Armendariz v. INS, 222 F.3d 728, 749 (9th Cir. 2000).

232. See Cardenas-Uriarte v. INS, 227 F.3d 1132, 1137-38 (9th Cir. 2000) (extending Lujan to allow expungement for conviction of simple possession of drug paraphemalia). In California, this would include being under the influence of a controlled substance (CAL. HEALTH \& SAFETY CoDE $\$ 11550$ ), visiting a place where drugs are used (CAL. HEALTH \& SAFETY CODE $\$ 11365$ ), and the like. 
since a first-time drug offender is hopefully sympathetic enough to receive a plea bargain that would avoid conviction altogether for a removable offense. Nonetheless, defense counsel should be aware of this option in those rare cases where a more favorable plea bargain may not be obtained.

\section{CONCLUSION}

AEDPA and IIRAIRA have dramatically expanded the criminal grounds for removal by broadening the definition of "aggravated felony" and "conviction." Those facing removal based on an aggravated felony are no longer eligible for discretionary relief and are ineligible for judicial review of a final deportation order. Intolerance toward criminal immigrants is deeply entrenched in our society and proposals to increase the protections afforded criminal immigrants will be a bitter pill for many to swallow. Why, people may ask, should we allow someone who is committing crime in our neighborhoods to stay here? The answer is that IIRAIRA and AEDPA have ensnared in their nets people convicted of minor crimes; while such crimes warrant punishment, they do not justify removal. Some of those removed for criminal convictions were brought to the United States as small children or have spouses and children who are United States citizens. Removal for these people may tear them from their families and send them to a country that is entirely foreign to them, where they know no one, have no job, and may not even speak the language.

The standard of effective representation of noncitizens in criminal proceedings should reflect the changing state of immigration law. Imposing a duty on defense counsel to investigate and advise noncitizen clients of the immigration consequences of a guilty plea will simply ensure that noncitizens make intelligent decisions about their own fates. The ABA standards, which Strickland advises courts to use as a guide in assessing reasonable performance, support imposing a duty to investigate and advise clients of immigration consequences. Furthermore, averting immigration consequences does not unduly burden defense attorneys. Defense counsel need only gather basic information about the client's immigration status and the offense charged, consult an immigration attorney, and offer information about the immigration consequences to the district attorney in negotiating a plea bargain that will avoid removal. These steps may cost the attorney one to two hours of time and ten dollars for a five-minute consultation with an immigration attorney. While this does require extra effot, such mininal additional efforts can hardly be called a burden, considering that the alternative is to risk the client's permanent banishment from the United States. 